\title{
Integrating Global Satellite-Derived Data Products as a Pre-Analysis for Hydrological Modelling Studies: A Case Study for the Red River Basin
}

\author{
Gijs Simons 1,2,*, Wim Bastiaanssen 1,3, Le An Ngô ${ }^{4}$, Christopher R. Hain ${ }^{5}$, Martha Anderson ${ }^{6}$ \\ and Gabriel Senay ${ }^{7}$ \\ 1 Faculty of Civil Engineering and Geosciences, Department of Water Management, Delft University \\ of Technology, Stevinweg 1, Delft 2628 CN, The Netherlands; wim.bastiaanssen@gmail.com \\ 2 FutureWater, Costerweg 1V, Wageningen 6702 AA, The Netherlands \\ 3 UNESCO-IHE, Westvest 7, Delft 2611 AX, The Netherlands \\ 4 Faculty of Hydrology and Water Resources, Thuy Loi University, 175 Tay Son, Dong Da, Ha Noi, Vietnam; \\ annl@wru.vn \\ 5 Earth System Science Interdisciplinary Center, University of Maryland, College Park, MD 20742, USA; \\ Chris.Hain@noaa.gov \\ 6 Hydrology and Remote Sensing Labaratory, USDA-ARS, Beltsville, MD 20705, USA; \\ martha.anderson@ars.usda.gov \\ 7 USGS EROS Center, North Central Climate Science Center, Colorado State University, Fort Collins, \\ CO 80523, USA; senay@usgs.gov \\ * Correspondence: g.w.h.simons@tudelft.nl; Tel.: +31-317-460-050
}

Academic Editors: Magaly Koch and Prasad S. Thenkabail

Received: 14 January 2016; Accepted: 21 March 2016; Published: 28 March 2016

\begin{abstract}
With changes in weather patterns and intensifying anthropogenic water use, there is an increasing need for spatio-temporal information on water fluxes and stocks in river basins. The assortment of satellite-derived open-access information sources on rainfall $(\mathrm{P})$ and land use/land cover (LULC) is currently being expanded with the application of actual evapotranspiration ( $\mathrm{ET}_{\text {act }}$ ) algorithms on the global scale. We demonstrate how global remotely sensed $\mathrm{P}$ and $\mathrm{ET}_{\text {act }}$ datasets can be merged to examine hydrological processes such as storage changes and streamflow prior to applying a numerical simulation model. The study area is the Red River Basin in China in Vietnam, a generally challenging basin for remotely sensed information due to frequent cloud cover. Over this region, several satellite-based $\mathrm{P}$ and $\mathrm{ET}_{\text {act }}$ products are compared, and performance is evaluated using rain gauge records and longer-term averaged streamflow. A method is presented for fusing multiple satellite-derived $\mathrm{ET}_{\text {act }}$ estimates to generate an ensemble product that may be less susceptible, on a global basis, to errors in individual modeling approaches. Subsequently, monthly satellite-derived rainfall and $\mathrm{ET}_{\text {act }}$ are combined to assess the water balance for individual subcatchments and types of land use, defined using a global land use classification improved based on auxiliary satellite data. It was found that a combination of TRMM rainfall and the ensemble $\mathrm{ET}_{\text {act }}$ product is consistent with streamflow records in both space and time. It is concluded that monthly storage changes, multi-annual streamflow and water yield per LULC type in the Red River Basin can be successfully assessed based on currently available global satellite-derived products.
\end{abstract}

Keywords: global satellite-derived data; intercomparison; evapotranspiration; Red River Basin; hydrological modeling; water accounting

\section{Introduction}

Global surface and ground water resources are under increasing pressure from human water use and climate change [1-3]. Well-informed decision-making on water management is essential for coping 
with tensions between water availability and water demand. This requires a feasible methodology for quantifying the current state of water resources in terms of hydrological flows and connectivity, as well as indicators of water use and reuse [4]. Once reasonable estimates of these quantities have been established, simulation models can be used to examine the predicted consequences of different scenarios related to policy adjustments, climate change, land use modifications, etc. (e.g., [5]).

The fundamental components of the water balance that need to be quantified include precipitated water, consumed water, water withdrawals, and non-consumed water with varying definitions and sub-classifications to be found in widely used water assessment frameworks such as Water Footprint [6], Water Accounting Plus (WA+) [7], and System of Environmental-Economic Accounts for Water (SEEA-Water) [8], among others. Relating precipitation and/or withdrawals to consumptive use through evapotranspiration provides a basis for an assessment of weekly or monthly surplus (i.e., groundwater recharge, drainage, surface runoff dynamics) or deficit (i.e., irrigation, inundation, return flows and their reuse). The role of soil water storage changes is essential at smaller time scales and should get sufficient attention [9].

Satellite-derived datasets have been increasingly put to use in the field of water resources management at a range of different spatio-temporal scales. They provide valuable information in poorly gauged or inhospitable areas and transcend political borders. By now, methodologies for deriving precipitation $(\mathrm{P})$ and actual evapotranspiration $\left(\mathrm{ET}_{\text {act }}\right)$ from remotely sensed data are well-established [10-12]. For purposes of water accounting, identification of management options and relating water consumption to services and benefits, it is desirable to relate the quantified flows to types of land use and land cover (LULC) within a river basin or, ideally, to individual water users. This facilitates a description of water users in a river basin in terms of their dependency on water from different sources, as well as the extent to which they "produce" water for potential downstream reuse [4].

A number of global-scale satellite-derived data products (GSDPs) for $\mathrm{P}, \mathrm{ET}_{\mathrm{act}}$ and LULC are available. Many of these are already in the public domain or soon to be released, which makes them a valuable and easily accessible resource for water management researchers, consultants and policy makers. Scientific literature provides a substantial body of review work on these products and their fundamental algorithms. Open-access rainfall GSDPs are extensively evaluated in scientific literature for a variety of geographical areas across the globe, e.g., [13-18]. Existing GSDPs on LULC and their validation are discussed for example by Mora et al. [19] and Tsendbazar et al. [20]. Conversely, global-scale $\mathrm{ET}_{\text {act }}$ products based on remote sensing are relatively new. A wealth of literature on satellite-based techniques for quantifying $\mathrm{ET}_{\mathrm{act}}$ is available [21] and the basic algorithms are well-documented [22-26]. Many institutions are now taking the next step by developing and distributing operational evapotranspiration products for the globe at spatial resolutions of $\leqslant 5 \mathrm{~km}$. $\mathrm{ET}_{\text {act }}$ GSDPs provide independent datasets for calibrating hydrological models and land surface models. Comparative analyses of $\mathrm{ET}_{\text {act }}$ models applied on the continental to global scales have recently come available and typically compare two individual satellite-derived $\mathrm{ET}_{\text {act }}$ products for specific regions [27-31], some also including $\mathrm{ET}_{\text {act }}$ outputs from global hydrological models and land surface models [32]. Comprehensive evaluations of a larger number of satellite-derived $\mathrm{ET}_{\text {act }}$ estimates, in the style of the many P assessments that are available, have so far only sparsely been conducted [33,34]. This is related to the limited availability of these products in the public domain up to now, which is currently changing rapidly.

Some recent papers have focused on integrating rainfall, $\mathrm{ET}_{\text {act }}$ and LULC GSDPs and their combined potential for assessments of water resources. Bastiaanssen et al. [35] successfully computed the annual water balance of the Nile basin, including net withdrawals. Wang-Erlandsson et al. [36] demonstrated how global $\mathrm{P}$ and $\mathrm{ET}_{\text {act }}$ time series can be used to compute the storage capacity of the root zone. The integrated use of satellite-derived $\mathrm{P}$ and $\mathrm{ET}_{\mathrm{act}}$ is a reality check on a pixel-by-pixel basis and an opportunity to check data quality that goes beyond the comparison with individual rain gauges or eddy covariance towers, which both cover very limited areas. If quality is found to be satisfactory, 
such data can be integrated in hydrological modeling procedures on the regional and global scale. In addition, Hain et al. [37] demonstrated how $\mathrm{ET}_{\text {act }}$ retrieved from energy balance can be combined with an inferred local water balance to diagnose ancillary sources and sinks of moisture across landscapes, e.g., due to intensive irrigation or agricultural drainage, or access to shallow water tables.

In this paper, we aim to: (1) demonstrate how integrating satellite-derived $\mathrm{P}, \mathrm{ET}_{\text {act }}$ and LULC maps constitutes an important pre-analysis in the first stages of hydrological modeling; (2) show that consistency between hydrological variables is a way to evaluate and compare individual earth observation products, with a focus on five new global $\mathrm{ET}_{\text {act }}$ products; and (3) evaluate the suitability of global satellite-derived data products for assessing water resources in a basin with challenging conditions for remote sensing. We present our case in the context of the transboundary Red River Basin in Southeast Asia, traditionally a problematic region for remote sensing because of weather patterns, but also a basin with pressing water management issues where limited international data sharing hampers a comprehensive understanding of basin water use and hydrology.

\section{Materials and Methods}

\subsection{Study Area}

The Red River Basin (Figure 1) can be roughly divided in an upstream half situated in the province of Yunnan in southern China and a downstream half in northern Vietnam, with a minor portion of less than $1 \%$ located in Lao PDR. Its total surface area is approximately $164,000 \mathrm{~km}^{2}$. The Red River has two main tributaries: Da River (Lixian in Chinese) and Lo River (Panlong). The upstream part of the basin is largely forested, mountainous and sparsely populated. The delta of the Red River, downstream of the confluence of the three major branches, is a densely populated area of great importance to Vietnam for its agricultural productivity and economic activity.

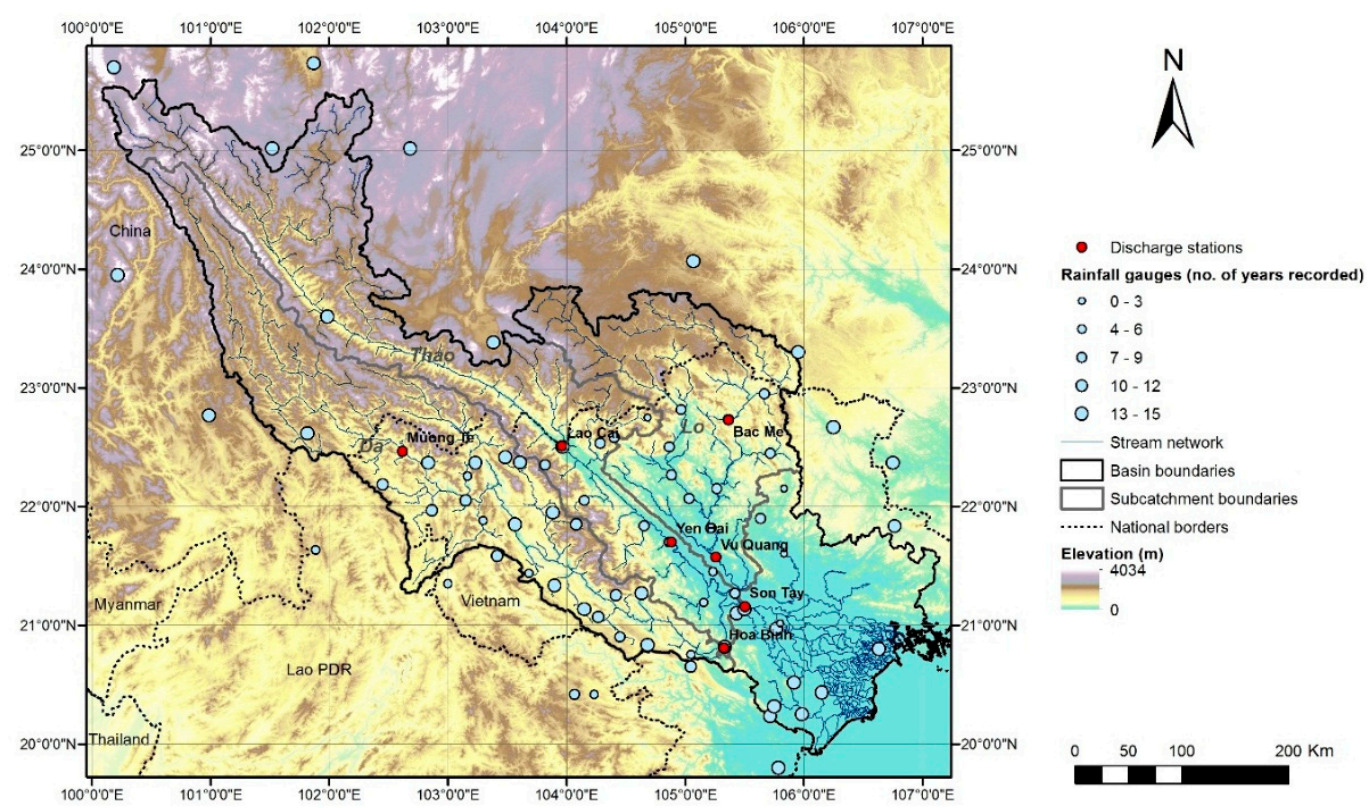

Figure 1. The Red River Basin. Elevation was obtained from the Shuttle Radiometer Topography Mission (SRTM) data, and the main river network and catchment boundaries were derived from the SRTM elevation map. The stream network downstream of Son Tay mainly consists of irrigation canals and was provided by the Institute of Water Resource Planning (IWRP) in Vietnam.

Annual rainfall varies substantially across the Red River Basin, with values between 700 and $3000 \mathrm{~mm}$ found based on long-term station time series [38,39], while even local annual averages of over $4000 \mathrm{~mm}$ /year are reported [40]. Approximately $80 \%$ of this rainfall occurs in the months May 
to October, which comprise the wet season for both the Vietnamese and the Chinese portion of the basin [41]. The resulting variability of river discharge in space and time, as well as population growth, lead to substantial challenges related to flood control and water stress, particularly in Vietnamese territories [42]. Water management options across the basin have increased with the construction of five large multi-purpose reservoirs in the Vietnamese Da River and tributaries of the Lo River, as well as manifold smaller hydropower dams in both China and Vietnam. However, this has also increased the need for spatiotemporal data on water availability to support reservoir management [43].

At the tail end of the basin, the Red River Delta has seen many centuries of human water management, from the construction of hydraulic works for protection from floodwaters to the support of irrigation by avoiding inflow of brackish water and enhancing land drainage, making use of tidal influences if possible. Three zones can be distinguished: the lowlands, midlands, and highlands, based on their elevation relative to the water table [44]. The spatial distribution of water resources across the Delta is unequal, with some areas approaching the minimum level of water availability required to "sustain life and agricultural production" [45]. Most of the surface area of the Delta is characterized by rice paddies for a major part of the year. Typically, two rice seasons are observed, an irrigation-dependent spring season and a rainfall-dependent summer season [46]. If irrigation water availability allows, farmers grow a third "dry" crop such as vegetables or maize during the October-February period, particularly in the highlands and midlands. Reuse of drainage water within irrigation schemes is substantial [47]. Still, non-consumed irrigation water is one of the main sources of aquifer recharge, and thus of industrial and domestic water supply [48]. The outflow from the complex stream network of the Red River Delta into the Gulf of Tonkin occurs through nine different outlets [49].

\subsection{Land Use/Land Cover}

The current application requires an accurate and recent LULC map covering northern Vietnam/southern China with a sufficient level of spatial detail, validity for a year within the past 10-15 years and distinguishing between classes relevant for the nature of water use, including a class for irrigated cropland. An overview of existing global LULC maps is provided by Mora et al. [19], with spatial resolutions ranging from mid-resolution $(300-500 \mathrm{~m})$ to lower resolution $(\geqslant 1 \mathrm{~km})$ products. In addition, the first high-resolution Landsat-based global LULC products are now also available [50,51]. The number of classes of the available LULC maps varies from 9 to 37, and years of coverage from 1992 to 2012. Based on the criteria mentioned above, in particular Globcover 2009 [52] and GLCNMO2008 [53] were identified as potentially suitable inputs to this study.

Accuracies of global LULC products were previously found to be in the range of $69 \%-87 \%$ [12]. Ongoing initiatives such as the Global Observation for Forest Cover and Land Dynamics (GOFC/GOLD) of ESA seek to enhance the quality of global LULC products. In the meantime, auxiliary satellite images from the public domain are helpful to enhance LULC maps for a specific region. We adopted an approach of deriving an optimized LULC map for the Red River Basin derived from a combination of existing LULC GSDPs and time series of freely available MODerate resolution Imaging Spectroradiometer (MODIS) satellite images [54] a proven methodology for improving the accuracy of LULC maps [55,56]. Regional-scale improvement of global land cover products, incorporating auxiliary data and a priori knowledge, leads to more accurate and actionable water accounting information.

The 300 m Globcover 2009 map was taken as the basis for the new LULC map. Although the spatial distribution of forested and shrubland classes seems in accordance with expert knowledge, the original Globcover 2009 product largely contains rainfed cropland pixels for the Red River Delta. This is erroneous when viewed against the abundant presence of irrigation infrastructure. However, there is a blurred line between rainfed and irrigated agriculture in the region, as the wet-season is likely rainfed in both classes, with water coming from rainfall or recession of seasonal floods [57]. The main 
distinctive feature between locations with a single, exclusively rainfed crop and multi-cropped areas with at least one irrigated cycle is therefore the occurrence of a winter and/or spring crop [58].

According to the Globcover 2009 validation report [59], irrigated pixels are regularly misclassified as other agricultural classes. Therefore, to correct the Globcover 2009 agricultural classes, first all cells containing $>50 \%$ cropland were merged into a single cropland class. MODIS Normalized Difference Vegetation Index (NDVI) values within the merged cropland class during the spring season were decisive in distinguishing irrigated from rainfed agriculture. Pixels covered by clouds, as indicated by the MODIS pixel reliability layer, were omitted from this analysis. No gapfilling of individual images was performed, in order to only include pixels directly sensed by MODIS with sufficient quality. An average NDVI of at least 0.55 in the months March to May was used as a criterion for identifying irrigation, in accordance with the typical Red River Delta spring cropping cycle. A different cropping calendar was identified from NDVI time series analyses for the northern parts of the basin, with a pronounced peak during January. For this reason, a second precondition of a minimum NDVI of at least 0.55 in January was introduced to account for irrigation in the upstream portion of the basin. The underlying assumption is that an NDVI of 0.55 for cropland in the Red River Basin cannot be achieved in January or March-May by relying solely on rainwater.

In addition to the correction of the Globcover 2009 cropland classification, a visual assessment of the original map against high-resolution satellite imagery indicated an underestimation of urban area in the Red River basin. It was observed that the urban land use class of GLCNMO2008 is more realistic and these cells were therefore introduced to represent built-up area in the improved LULC map. As a final step, isolated pixels were filtered out using a GIS focal majority filter.

MODIS NDVI time series of three major classes in the final LULC map are displayed in Figure 2. While some noise is apparent due to the different cloud masks applied to each of the individual images, distinct temporal patterns are clearly identified. The second annual cropping season in the irrigated class is clearly visible when compared to the rainfed cropland. A third, less pronounced peak of irrigated NDVI values can be observed in the winter months. Year-to-year differences of winter and spring crop NDVI are illustrative of varying water availability. As is to be expected, average NDVI of the merged forested class remains relatively stable and high $(>0.5)$ throughout the entire year.

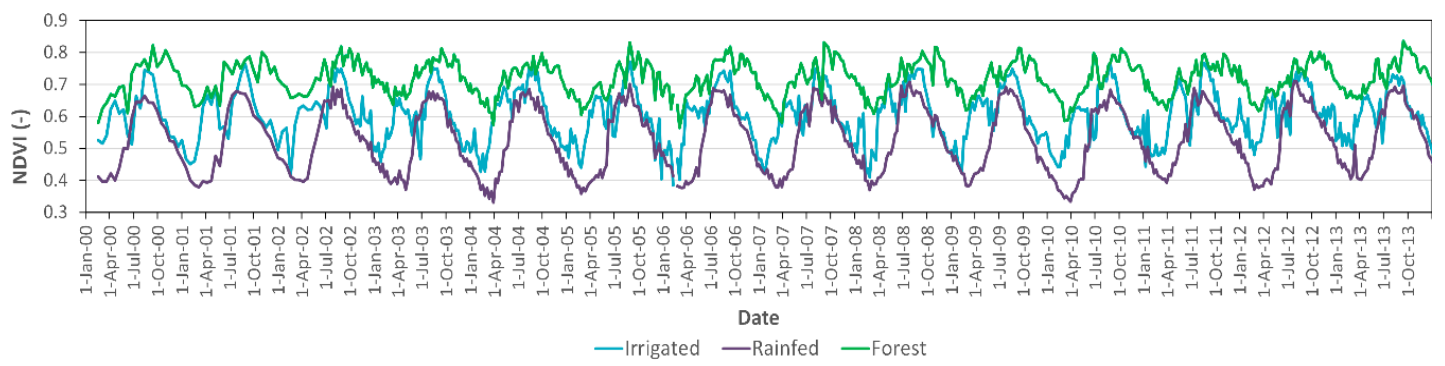

Figure 2. Normalized Difference Vegetation Index (NDVI time series of three main Land Use / Land Cover (LULC) classes in 2000-2014 based on the 250 meter MODIS NDVI products MOD13Q2 and MYD13Q2. "Forest" is comprised of all forested classes in the Globcover 2009 product.

The final, enhanced LULC map is depicted in Figure 3. Visual comparison with the recently released IWMI map of irrigation in Asia [60], retrieved 19 November 2015) shows similar spatial distributions of rainfed and irrigated land. As the Red River Delta has been the main focus area of previous studies, availability of validation data is mainly limited to this area. The modifications to the original Globcover 2009 yield a total irrigated area of 869,029 ha in the 10 provinces that together make up the Red River Delta administrative region. Literature sources report irrigated acreages varying from 670,000 to 850,000 ha, although the exact spatial and temporal scope of these figures is not always specified in these studies [43,45,61-63]. These values are all somewhat lower than the acreage found in a recent Advanced Synthetic Aperture Radar (ASAR)-based study, reporting 1,180,000 ha 
of double-cropped rice for 2007-2011 [58], so some uncertainty persists. Overall, the new LULC map corresponds well with the majority of available information from other sources and suffices for the current purpose.

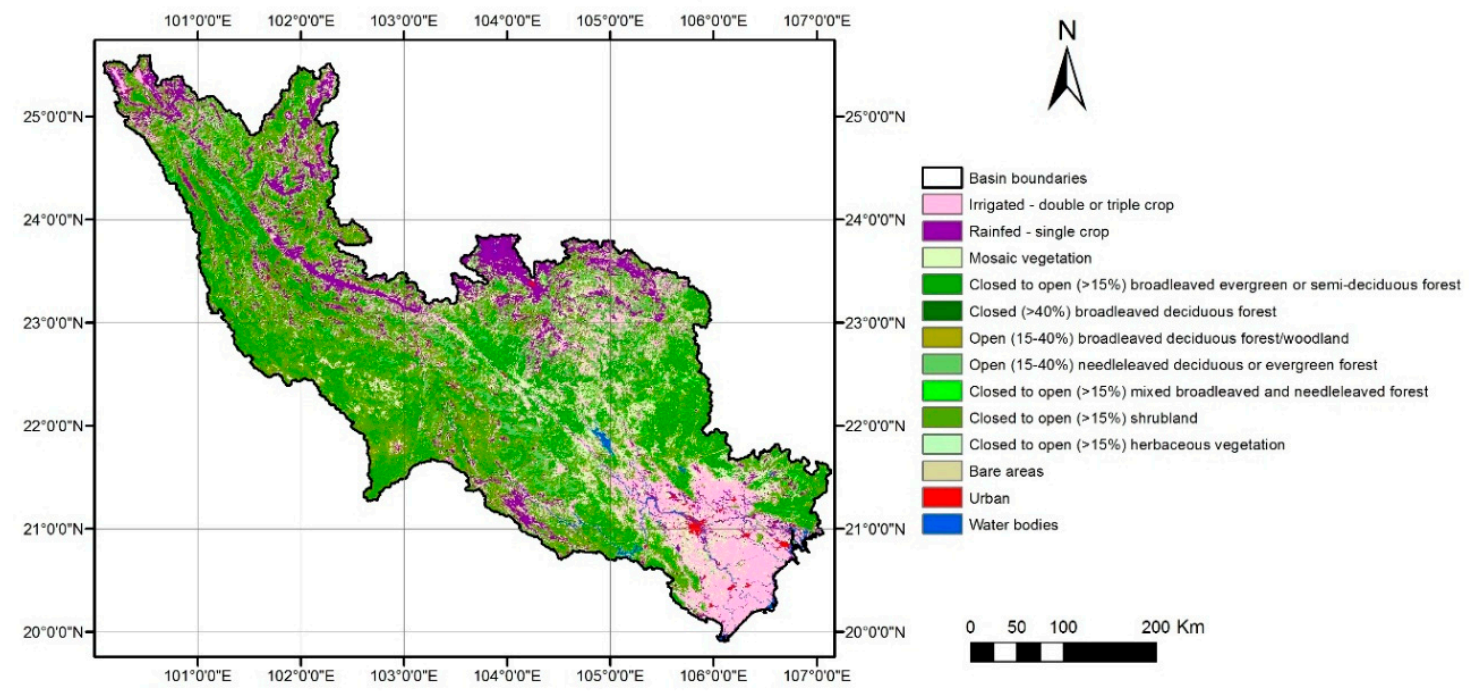

Figure 3. LULC map of the Red River Basin.

\subsection{Rainfall}

A spatially distributed monthly rainfall product is required which covers the Red River Basin for the last 10-15 years. Existing rainfall GSDPs with over 10 years of data in the period 2000 to present and a spatial resolution of $\leqslant 0.25$ degree were downloaded and evaluated: the Tropical Rainfall Measurement Mission monthly best estimate (TRMM 3B43 v7), the global rainfall estimate based on the CPC MORPHing technique (CMORPH) and the Climate Hazards Group InfraRed Precipitation with Station dataset (CHIRPS v1.8). Since no readily available CMORPH monthly product exists, three-hourly data were aggregated to obtain monthly values. Table 1 presents the main characteristics of the rainfall GSDPs evaluated for the Red River Basin.

Table 1. Evaluated rainfall GSDPs for the Red River Basin. The basin-wide mean rainfall $(\mu)$ and year-to-year standard deviation $(\sigma)$ are reported for the overlapping period (January 2003-December 2014). April-September and October-March rainfall statistics are listed separately to reflect the regional seasonality of rainfall.

\begin{tabular}{|c|c|c|c|c|c|c|c|c|c|}
\hline \multirow{2}{*}{ Product } & \multirow{2}{*}{$\begin{array}{l}\text { Temporal } \\
\text { Coverage }\end{array}$} & \multirow{2}{*}{$\begin{array}{l}\text { Original/Applied } \\
\text { Resolution }\end{array}$} & \multirow{2}{*}{$\begin{array}{c}\text { Key } \\
\text { References }\end{array}$} & \multicolumn{2}{|c|}{$\begin{array}{c}\text { Annual P } \\
(\mathrm{mm})\end{array}$} & \multicolumn{2}{|c|}{$\begin{array}{l}\text { Apr-Sep P } \\
(\mathbf{m m})\end{array}$} & \multicolumn{2}{|c|}{$\begin{array}{c}\text { Oct-Mar } \\
\text { Rainfall (mm) }\end{array}$} \\
\hline & & & & $\mu$ & $\sigma$ & $\mu$ & $\sigma$ & $\mu$ & $\sigma$ \\
\hline TRMM 3B43 v7 & $\begin{array}{l}\text { January 1998- } \\
\text { October } 2015\end{array}$ & $0.25^{\circ} / 25 \mathrm{~km}$ & [64] & 1545.7 & 121.8 & 1301.6 & 69.9 & 244.1 & 61.0 \\
\hline CHIRPS v1.8 & $\begin{array}{c}\text { January 1981- } \\
\text { present }\end{array}$ & $0.05^{\circ} / 5 \mathrm{~km}$ & [65] & 1403.2 & 115.2 & 1223.1 & 88.4 & 180.0 & 40.2 \\
\hline CMORPH & $\begin{array}{c}\text { December } \\
\text { 2002- present }\end{array}$ & $0.25^{\circ} / 25 \mathrm{~km}$ & [66] & 1169.3 & 173.2 & 1070.8 & 150.8 & 98.5 & 39.5 \\
\hline
\end{tabular}

In order to select the most accurate rainfall product for the target basin, the performance of each of the GSDPs was assessed by means of ground observations. Daily rainfall station data were purchased from the Vietnamese National Center for Hydro-Meteorological Forecasting (NCHMF) and downloaded from the NOAA Global Summary of the Day (GSOD) database, as distributed by the National Climatic Data Center (NCDC). In total, multiple years of rainfall data for 76 gauges were 
available for GSDP validation. Figure 1 indicates the location and amount of data available for each station. A full list of all rain gauges can be found in Table A1. Data from $62 \%$ of these stations are not provided in the public domain and are therefore particularly suitable for validation, since the TRMM and CHIRPS algorithms incorporate a calibration procedure based on open-access rainfall gauge measurements. Nevertheless, it was decided to also include public GSOD data in this validation exercise as otherwise no validation data from Chinese territories would be available.

Figure 4 shows plots of satellite-derived monthly rainfall data against rain gauge measurements. Of the three evaluated products, the TRMM regression line is closest to the line of 1:1 correspondence, followed by CHIRPS and CMORPH respectively. A few outliers are clearly visible, where high gauged rainfall amounts do not correspond with satellite-derived estimates. These were all recorded at the Bac Quang station. It is unclear if this signifies a problem with the measurement station or the GSDPs. However, as these 10 points make up only a minor portion of the total number of monthly rainfall values evaluated $(10,368)$, their impact on further analyses is negligible.
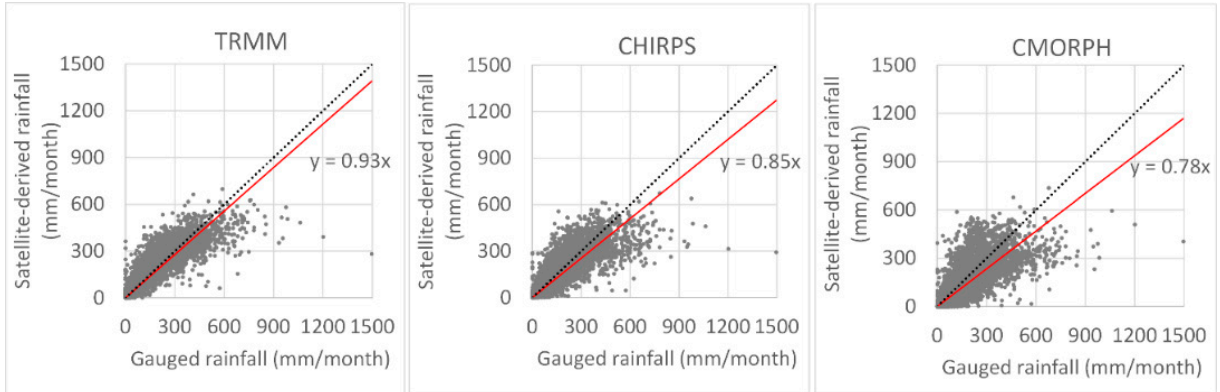

Figure 4. Comparison of monthly rain gauge data with three satellite products for the overlapping period January 2003-December 2014. The dashed line indicates a 1:1 correspondence and the red line gives the linear regression best fit with 0 intercept.

The error in monthly rainfall estimates for each of the products is further evaluated in Figure 5. With $-5.83 \mathrm{~mm}$, CHIRPS has a slightly lower error than TRMM, while the mean error of CMORPH monthly rainfall estimates are furthest from measured values. It is interesting to note that, although the CHIRPS mean error is lower than the TRMM mean error, the standard deviation of the CHIRPS error is higher as a result of the amount of months with large error values. Table 2 lists a number of other commonly used validation statistics. These indicate a favorable performance of TRMM in terms of the relationship between measured and estimated values $(r)$, the relative mean absolute error (RMAE), and the predictive power of the algorithm relative to the gauged mean (Nash-Sutcliffe coefficient).

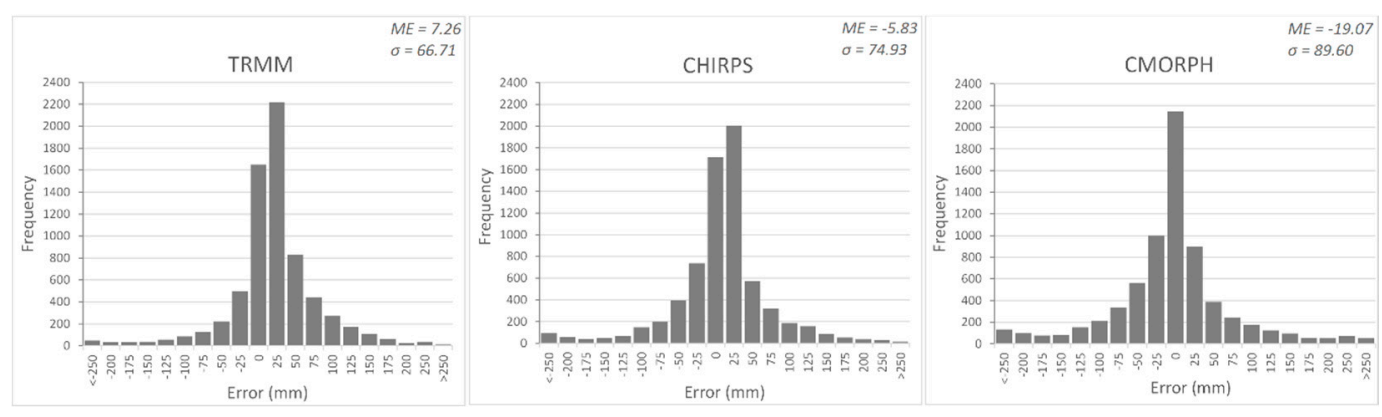

Figure 5. Frequency distributions of the error in monthly rainfall. Indicated are the mean error (ME) and standard deviation $(\sigma)$ in $\mathrm{mm}$. 
Table 2. Other pairwise validation statistics for three satellite products (S) based on all available station records $(G)$ during the overlapping period (January 2003-December 2014).

\begin{tabular}{|c|c|c|c|c|}
\hline Indicator & Formula & CHIRPS & TRMM & CMORPH \\
\hline Pearson correlation coefficient $\mathrm{r}(-)$ & $r=\frac{\sum(G-\bar{G})(S-\bar{S})}{\sqrt{\sum(G-\bar{G})^{2}} \sqrt{\sum(S-\bar{S})^{2}}}$ & 0.851 & 0.884 & 0.786 \\
\hline Relative Mean Absolute Error RMAE (-) & $R M A E=\frac{1}{n} * \frac{\sum|(S-G)|}{\bar{G}}$ & 0.327 & 0.296 & 0.427 \\
\hline $\begin{array}{l}\text { Nash-Sutcliffe Model Efficiency } \\
\text { Coefficient NS }(-)\end{array}$ & $N S=1-\frac{\sum(S-G)^{2}}{\sum(G-\bar{G})^{2}}$ & 0.721 & 0.777 & 0.585 \\
\hline $\operatorname{Bias}(-)$ & Bias $=\frac{\sum(S)}{\sum(G)}$ & 0.956 & 1.055 & 0.857 \\
\hline
\end{tabular}

Based on the findings discussed above, TRMM was identified as the most suitable GSDP for describing monthly rainfall in the Red River basin. This is in line with earlier findings that TRMM is the most favorable option for satellite-derived rainfall on the monthly scale in an area in southern China [67], and a successful application of TRMM precipitation in a modeling study in central Vietnam [68]. Apparently, for the Red River Basin, the higher spatial resolution of the CHIRPS product does not lead to a more accurate assessment of rainfall when compared to the point scale. It should be noted that some of the GSOD stations used for validation may also have been part of the TRMM and CHIRPS algorithms, whereas CMORPH is uncorrected for station values.

It is often decided to perform a bias-correction of rainfall GSDPs based on ground observations. However, special attention should go to the issue of scale when comparing point measurements of rainfall gauges to coarse pixels [69]. Naturally, a $25 \mathrm{~km}$ pixel can be quite heterogeneous e.g., in terms of topography, and different rainfall rates may occur over short distances within a grid cell. Vernimmen et al. [70] discuss in detail how the presence of multiple ground stations within a grid cell enhances opportunities for validation. In the Red River Basin, five TRMM pixels were identified containing two rainfall stations (Figure A1). The records of these gauges were averaged per pixel and plotted against TRMM values. This resulted in a slope of the fitted line of 0.97 (Figure A2). This increase relative to 0.93 (Figure 4) indicates that performance of TRMM seems satisfactory in terms of representing intra-pixel variability. Although the sample size is insufficient to draw any definitive conclusions, this brief analysis does not provide a reason for assuming that a point-based bias correction would improve the 25-km TRMM rainfall estimate.

\subsection{Actual Evapotranspiration}

\subsubsection{Available $\mathrm{ET}_{\text {act }}$ Products}

While the network of rain gauges in the Red River Basin is sufficient to arrive at a well-informed choice of an optimal GSDP for precipitation, this is unfortunately not the case for evapotranspiration. No network of $\mathrm{ET}_{\text {act }}$ measurements is available for the Red River Basin, limiting the foundation for selecting a single $\mathrm{ET}_{\text {act }}$ GSDP. We therefore take an ensemble approach to defining $\mathrm{ET}_{\text {act }}$ across the basin, combining information from multiple GSDPs.

In this study, five $\mathrm{ET}_{\text {act }}$ products were evaluated with a coverage of the Red River Basin at a spatial resolution of $\leqslant 5 \mathrm{~km}$ with a time series of over 10 years: the MODIS Global Terrestrial Evapotranspiration Product (MOD16, [22]), the Operational Simplified Surface Energy Balance (SSEBop, [23]), the revised Surface Energy Balance System (SEBS, [25]), CSIRO MODIS Reflectance Scaling actual ET (CMRSET, [24]), and the Atmosphere-Land Exchange Inverse (ALEXI) water and energy budget model [71]. Although these products all use MODIS satellite data to some extent, their fundamental modeling strategies are markedly different. SSEBop and SEBS rely on MODIS land surface temperature (LST) data for determination of the latent heat flux. ALEXI uses a similar approach but integrates a range of different spaceborne data sources. CMRSET combines a vegetation index for estimating photosynthetic activity with shortwave infrared reflections to estimate vegetation water 
content and presence of standing water. MOD16 follows the Penman-Monteith logic and relies on visible and near-infrared data to account for Leaf Area Index (LAI) variability. The latter is currently the only global product that has been tested and reviewed in a substantial number of scientific articles [29]. For a detailed description of each of the $\mathrm{ET}_{\text {act }}$ algorithms, the reader is referred to the citations listed in Table 3.

Table 3. Properties of evaluated $\mathrm{ET}_{\text {act }}$ products for the Red River Basin. The basin-wide mean $\mathrm{ET}_{\text {act }}(\mu)$ and year-to-year standard deviation $(\sigma)$ are reported for the overlapping period (January 2003-December 2012). Temporal coverages indicate the time series of each product that were (made) available for this study.

\begin{tabular}{|c|c|c|c|c|c|c|c|c|c|}
\hline \multirow{2}{*}{ Product } & \multirow{2}{*}{$\begin{array}{l}\text { Temporal } \\
\text { Coverage }\end{array}$} & \multirow{2}{*}{$\begin{array}{l}\text { Original/Applied } \\
\text { Resolution }\end{array}$} & \multirow{2}{*}{$\begin{array}{c}\text { Key } \\
\text { References }\end{array}$} & \multicolumn{2}{|c|}{$\begin{array}{c}\text { Annual ET } \text { act } \\
2003-2012(\mathrm{~mm})\end{array}$} & \multicolumn{2}{|c|}{$\begin{array}{c}\text { Apr-Sep } \\
\text { ET }_{\text {act }}(\mathrm{mm})\end{array}$} & \multicolumn{2}{|c|}{$\begin{array}{c}\text { Oct-Mar } \\
\text { ET }_{\text {act }}(\mathrm{mm})\end{array}$} \\
\hline & & & & $\mu$ & $\sigma$ & $\mu$ & $\sigma$ & $\mu$ & $\sigma$ \\
\hline MOD16(A2) & $\begin{array}{l}\text { January 2000- } \\
\text { December 2015 }\end{array}$ & $926 \mathrm{~m} / 1 \mathrm{~km}$ & {$[22,29]$} & 1008.9 & 21.0 & 625.7 & 10.5 & 383.2 & 10.1 \\
\hline SSEBop & $\begin{array}{l}\text { January 2003- } \\
\text { December } 2013\end{array}$ & $1 \mathrm{~km} / 1 \mathrm{~km}$ & {$[23,72]$} & 885.8 & 36.8 & 613.9 & 11.4 & 271.9 & 25.1 \\
\hline SEBS & $\begin{array}{l}\text { January 2001- } \\
\text { December } 2013\end{array}$ & $5 \mathrm{~km} / 5 \mathrm{~km}$ & [25] & 1153.8 & 65.2 & 724.9 & 22.2 & 428.9 & 49.6 \\
\hline CMRSET & $\begin{array}{l}\text { January 2000- } \\
\text { December } 2012\end{array}$ & $0.05^{\circ} / 5 \mathrm{~km}$ & [24] & 960.2 & 47.2 & 564.5 & 23.1 & 395.7 & 26.8 \\
\hline ALEXI & $\begin{array}{l}\text { January 2003- } \\
\text { December } 2014\end{array}$ & $0.05^{\circ} / 5 \mathrm{~km}$ & {$[71,73]$} & 1103.5 & 33.4 & 709 & 12.8 & 394.5 & 25.5 \\
\hline
\end{tabular}

ALEXI is the only model for which no preprocessed monthly product was available. Therefore weekly values were aggregated to monthly maps, with $\mathrm{ET}_{\text {act }}$ during weeks overlapping two months being proportionally divided over these months. Maps of annually averaged $\mathrm{ET}_{\mathrm{act}}$ for the Red River Basin in 2003-2012 retrieved from the five aforementioned methods can be found in Figure A3.

Table 3 lists the basin-averaged $\mathrm{ET}_{\text {act }}$ according to the individual products. The annual average ET $_{\text {act }}$ in 2003-2012 falls within a range of $268 \mathrm{~mm}$, with SSEBop on the low end and SEBS on the high end of the values. It is interesting to note that the standard deviation of seasonal sums in the dry season is higher than in the wet season for all products. This reflects the different ways in which the algorithms simulate evapotranspiration under stressed conditions; during the rainy season, $\mathrm{ET}_{\text {act }} \mathrm{Will}$ likely equal $\mathrm{ET}_{\text {pot }}$ most of the time. None of the retrieved annual $\mathrm{ET}_{\text {act }}$ amounts conflict with reported values for reference evapotranspiration in the Red River Basin [39], or with the basin annual average potential evapotranspiration (ET $\mathrm{E}_{\text {pot }}$ ) of $1306 \mathrm{~mm}$ according to a $1 \mathrm{~km}$ global dataset on long-term average monthly $\mathrm{ET}_{\text {pot }}$ distributed by CGIAR [74].

Karimi and Bastiaanssen [12] report a mean absolute percentage error of $5.4 \%$ for remote sensing-based $\mathrm{ET}_{\text {act }}$ estimations. However, the range of values in Table 3 indicates that algorithms developed for the global scale yield substantially different outlooks on the Red River Basin water balance. This is also visible when comparing the spatial patterns in Figure A3. Specific locations where $\mathrm{ET}_{\text {act }}$ values of the different products correspond or contradict can be observed in Figure A4, where a spatial depiction of the coefficient of variation $(\mathrm{CV})$ in annual average $\mathrm{ET}_{\text {act }}$ is provided per pixel. The highest $\mathrm{CV}$ values are observed in areas with high elevation along some of the subbasin boundaries, where especially SEBS deviates from the other GSDPs (see Figure A3). A high CV is also found in the coastal zone, possibly caused by differing methodologies for dealing with standing water, or differences in applied land/water masks.

Examining the monthly variability of $\mathrm{ET}_{\text {act }}$ for different LULC classes against a priori knowledge is a way to further evaluate the five models. Figure 6 shows how monthly $\mathrm{ET}_{\text {act }}$ varies for three major land use types: irrigated cropland, rainfed cropland and the merged forested classes. In general, the different products agree reasonably well in terms of temporal patterns in monthly $\mathrm{ET}_{\mathrm{act}}$, and no clear discrepancies are observed in relation to known monthly rainfall patterns. The least temporal variation is observed in CMRSET, and the highest in SEBS followed by SSEBop. Rainfed agriculture 
has generally the lowest $\mathrm{ET}_{\text {act }}$ of these three LULC classes, according to all products. It is found that all models compute a reduction in the difference between the rainfed and irrigated classes as the wet season progresses. This is to be expected to a certain extent, as rainfed crops will have access to

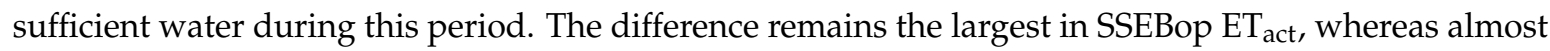
full convergence of the rainfed and irrigated CMRSET curves occurs from July onwards. MOD16 is the only model that predicts $\mathrm{ET}_{\text {act }}$ to be highest for the forest class throughout the year. ALEXI and CMRSET predict a very similar time series for the forested and irrigated classes, which may seem surprising as the physical conditions of these ecosystems are rather different. However, both forest and irrigated crops have access to ancillary moisture unavailable to rainfed crops (the forests due to deeper rooting depths), and with the current information it is difficult to determine which of the five temporal curves for these LULC types are most realistic. Despite the differences between products, Figure 6 does not provide sufficient basis for excluding any of the $\mathrm{ET}_{\text {act }}$ models from further analyses.

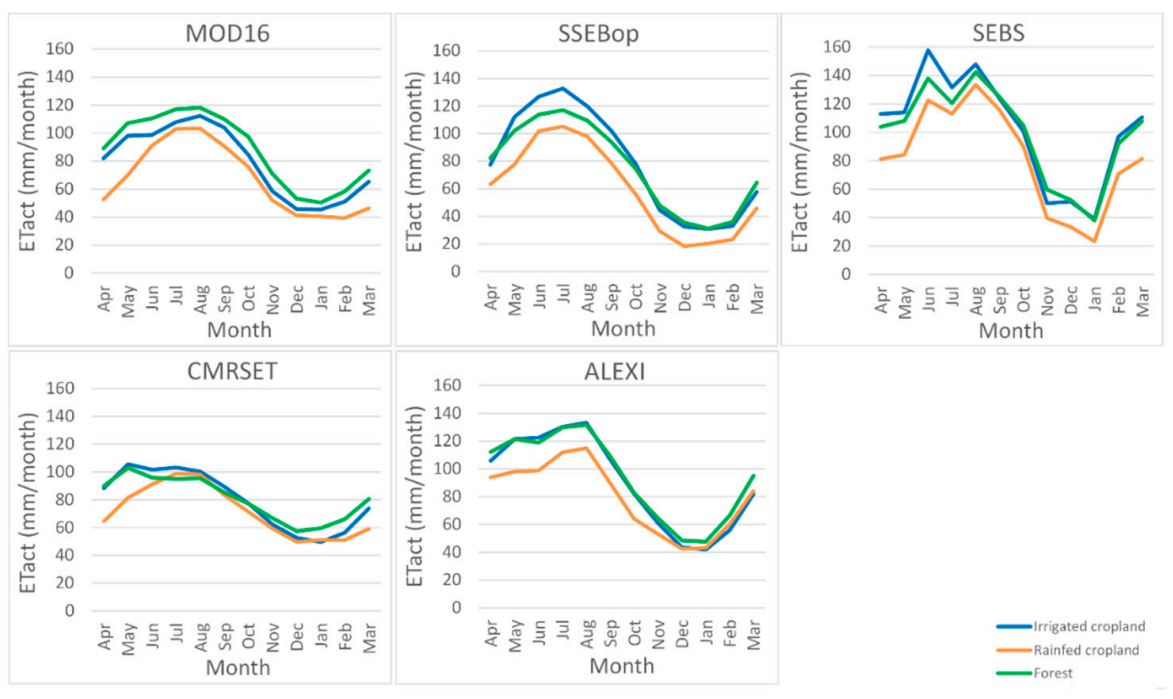

Figure 6. Average monthly $\mathrm{ET}_{\mathrm{act}}$ for three LULC types.

\subsubsection{Solving the Water Balance to Evaluate $\mathrm{ET}_{\mathrm{act}}$}

As the information available for the Red River Basin is insufficient to verify the quality of the $\mathrm{ET}_{\text {act }}$ products independently from rainfall, TRMM data were used in combination with streamflow records to check the closure of the water balance:

$$
Q=P-E T_{a c t}-\Delta S
$$

where $Q$ is measured river discharge and $\Delta S$ is the change in catchment storage. Fundamental hydrological principles and the law of mass conservation dictate that, over a number of hydrological years, the rainfall surplus $\left(\mathrm{P}-\mathrm{ET}_{\mathrm{act}}\right)$ should equal $\mathrm{Q}$ at the downstream end of a catchment. In this study, the storage change over a period of 10 years is assumed to be negligibly small. Time series of daily river discharge were purchased from the NCHMF for the hydrological stations indicated in Figure 1. Metadata of these stations are provided in Table A2. Using SRTM elevation data, upstream catchments were derived for each of the available measurement stations. Bac Me, Muong Te and Lao Cai are located in mountainous areas and all have a catchment located for the largest part in China. Hoa Binh, Yen Bai and Vu Quang are located at downstream points in the Da, Thao and Lo subbasins, respectively. The Son Tay station is located after of the confluence of the Da, Thao and Lo Rivers. No streamflow time series is measured downstream from Son Tay $[49,75]$.

First, a preliminary check of the reliability of these $Q$ data was performed by checking the consistency of temporal patterns between upstream and downstream stations in the same river 
branch (Figure A5). Although the upstream and downstream stations in the Da and Lo basins follow approximately the same pattern, the time series for the Thao River are quite different. For the years 2004 and 2005, hardly any runoff seems to be generated in the largely forested area of $14,000 \mathrm{~km}^{2}$ between Lao Cai and Yen Bai, while in 2003-2004 Q measurements downstream are even lower than upstream (in other words, net consumption seems to occur), which is impossible given the size and dominant LULC types of the area. As the Yen Bai discharge curve corresponds well with temporal patterns observed at other stations, it was decided to eliminate Lao Cai from further analyses. Averaged over the overlapping period of records, Yen Bai, Vu Quang and Hoa Binh, the three downstream stations in the subbasins, measure $92.8 \%$ of the total runoff at Son Tay. This is according to expectations, with the remaining $7.2 \%$ to be generated in the small intermediate area. In short, the analysis of streamflow records yields sufficient confidence in all available measurement stations, with the exception of Lao Cai.

It was decided to use long-term streamflow at one downstream gauging station to assess the area-averaged $\mathrm{ET}_{\mathrm{act}}$. Son Tay is the obvious choice, as it is located downstream of the confluence of the main tributaries and upstream of the Red River Delta, the main area of water demand. $\mathrm{ET}_{\text {act }}$ upstream from Son Tay was compared against TRMM rainfall and measured streamflow in Table 4. Hydrological years were defined from 1 April until 31 March of the subsequent calendar year, in order to include one full wet and dry season. Using this precipitation and streamflow dataset, SSEBop shows the best performance over this basin in terms of accordance with the laws of mass conservation, overestimating $\mathrm{P}$ minus $\mathrm{Q}$ by only $3.4 \%$. For all other $\mathrm{ET}_{\text {act }}$ products, values are found to exceed $\mathrm{P}$ minus $\mathrm{Q}$ with a range of $14.0 \%$ (CMRSET) to $34.3 \%$ (SEBS).

Table 4. TRMM rainfall (P), measured streamflow at Son Tay $(\mathrm{Q})$ and $\mathrm{ET}_{\mathrm{act}}$ from each of the products for the overlapping period of hydrological years. Only the area upstream of the gauging station has been considered.

\begin{tabular}{ccccccccc}
\hline \multirow{2}{*}{ Hydr. year } & \multirow{2}{*}{$\mathbf{P}(\mathbf{m m})$} & \multirow{2}{*}{$\mathbf{( m m})$} & \multirow{2}{*}{$\mathbf{*} \mathbf{Q}(\mathbf{m m})$} & \multicolumn{5}{c}{ ET $_{\text {act }}(\mathbf{m m})$} \\
\cline { 5 - 8 } & & & & MOD16 & SSEBop & SEBS & ALEXI & CMRSET \\
\hline $2003 / 2004$ & 1401.0 & 604.3 & 796.7 & 1023.0 & 821.5 & 1084.1 & 1110.1 & 946.4 \\
$2004 / 2005$ & 1590.3 & 703.0 & 887.3 & 984.4 & 860.7 & 1144.8 & 1059.1 & 911.5 \\
$2005 / 2006$ & 1452.5 & 701.4 & 751.1 & 1023.4 & 836.3 & 1065.7 & 1094.1 & 916.1 \\
$2006 / 2007$ & 1519.2 & 656.4 & 862.9 & 1006.5 & 826.9 & 1077.7 & 1124.7 & 918.8 \\
$2007 / 2008$ & 1615.8 & 761.3 & 854.5 & 1018.3 & 883.4 & 1196.5 & 1028.6 & 870.0 \\
$2008 / 2009$ & 1793.1 & 948.7 & 844.4 & 1017.1 & 884.8 & 1128.1 & 1067.8 & 1007.3 \\
$2009 / 2010$ & 1386.4 & 674.6 & 711.8 & 1006.5 & 821.2 & 1024.7 & 1124.3 & 978.7 \\
$2010 / 2011$ & 1482.5 & 594.8 & 887.7 & 970.0 & 917.0 & 1167.7 & 1065.5 & 986.3 \\
$2011 / 2012$ & 1423.8 & 531.8 & 892.0 & 1005.8 & 891.7 & 1165.7 & 1152.4 & 1001.2 \\
Average & 1518.3 & 686.3 & 832.0 & 1006.1 & 860.4 & 1117.2 & 1091.8 & 948.5 \\
\hline
\end{tabular}

It is important to realize that the aforementioned differences between $\mathrm{P}$ minus $\mathrm{Q}$ and $\mathrm{ET}_{\text {act }}$ are not only a product of uncertainties in satellite-derived $\mathrm{P}$ and $\mathrm{ET}_{\text {act }}$. A variety of factors cause a potentially significant uncertainty in streamflow records, with errors of $10 \%-20 \%$ not uncommon for single observations [76-78]. In the Red River Basin, local stage-discharge relations may become outdated after a number of years, depending on geology, in-stream sand mining and changes in erosion-sedimentation patterns due to reservoir construction. Specifically for the Son Tay gauging station, a error of $10 \%-15 \%$ in streamflow values was reported in 2014 [49]. Since the SSEBop retrieval of $\mathrm{ET}_{\mathrm{act}}$ falls well within this range of accuracy, we assume that it represents the upstream conditions most accurately in terms of absolute $\mathrm{ET}_{\text {act }}$. Still, the outcomes of such assessments should be regarded as comparative analyses, rather than absolute validation exercises.

\subsubsection{Construction of an Ensemble $\mathrm{ET}_{\text {act }}$ Product}

While $\mathrm{P}$ minus $\mathrm{Q}$ comparisons provide a means for assessing general reasonability of $\mathrm{ET}_{\mathrm{act}}$ retrievals at basin scales, they provide no information about the relative model accuracy in spatially distributing $\mathrm{ET}_{\mathrm{act}}$. Each of the algorithms incorporates different inputs, procedures and assumptions, 
leading to substantial differences in spatial patterns between models, which can be viewed in Figures A3 and A4. Previous studies demonstrated that the performance of a certain $\mathrm{ET}_{\text {act }}$ algorithm is dependent on factors such as LULC type, climate and the presence of mountains [27-29,33,34], meaning that the accuracy of $\mathrm{ET}_{\text {act }}$ predictions will vary across a basin. An ensemble approach was taken toward generating "best-guess" maps of $\mathrm{ET}_{\text {act }}$ in the Red River Basin, under the assumption that spatial errors between related yet differing mapping approaches will tend to cancel in the ensemble average. A superior performance of different $\mathrm{ET}_{\text {act }}$ ensemble products with respect to individual algorithms was previously observed for the Nile Basin [79], where flux towers were available for validation.

To identify models that are spatially most similar, spatial patterns were analyzed in terms of the Pearson correlation coefficient (r) at the pixel level (Table 5). A minimum value of 0.5 was assumed to represent a sufficiently strong spatial correlation to warrant combination in an ensemble $\mathrm{ET}_{\text {act }}$ product. It was found that the correlation between all pair-wise combinations of ALEXI, MOD16 and SSEBop was above this threshold, whereas CMRSET and SEBS do not achieve this level of correlation with any of the products. Pixel values of monthly ET $_{\text {act }}$ for ALEXI, MOD16 and SSEBop were scaled around 1 (the average for each product upstream of Son Tay) and the resulting maps were averaged to create a relative $\mathrm{ET}_{\text {act }}$ map for each month. Finally, these relative values were multiplied with the SSEBop $\mathrm{ET}_{\mathrm{act}}$ Son Tay catchment average. In this way, a final monthly $\mathrm{ET}_{\text {act }}$ product was constructed that is congruent with the basin water balance inferred from $\mathrm{P}$ minus $\mathrm{Q}$, as well as with the spatial patterns predicted by the majority of the available $\mathrm{ET}_{\mathrm{act}}$ GSDPs. The resulting annual ensemble $\mathrm{ET}_{\mathrm{act}}$ for the Red River Basin is presented in Figure 7.

Table 5. Pearson correlation coefficient of annually averaged $\mathrm{ET}_{\text {act }}$ pixel values in the entire Red River basin. Bold values are higher than 0.5 .

\begin{tabular}{cccccc}
\hline & ALEXI & CMRSET & MOD16 & SEBS & SSEBop \\
\hline ALEXI & & 0.249 & 0.679 & 0.181 & 0.714 \\
CMRSET & 0.249 & & 0.095 & 0.408 & 0.419 \\
MOD16 & 0.679 & 0.095 & & 0.111 & 0.539 \\
SEBS & 0.181 & 0.408 & 0.111 & & 0.383 \\
SSEBop & 0.714 & 0.419 & 0.539 & 0.383 & \\
\hline
\end{tabular}

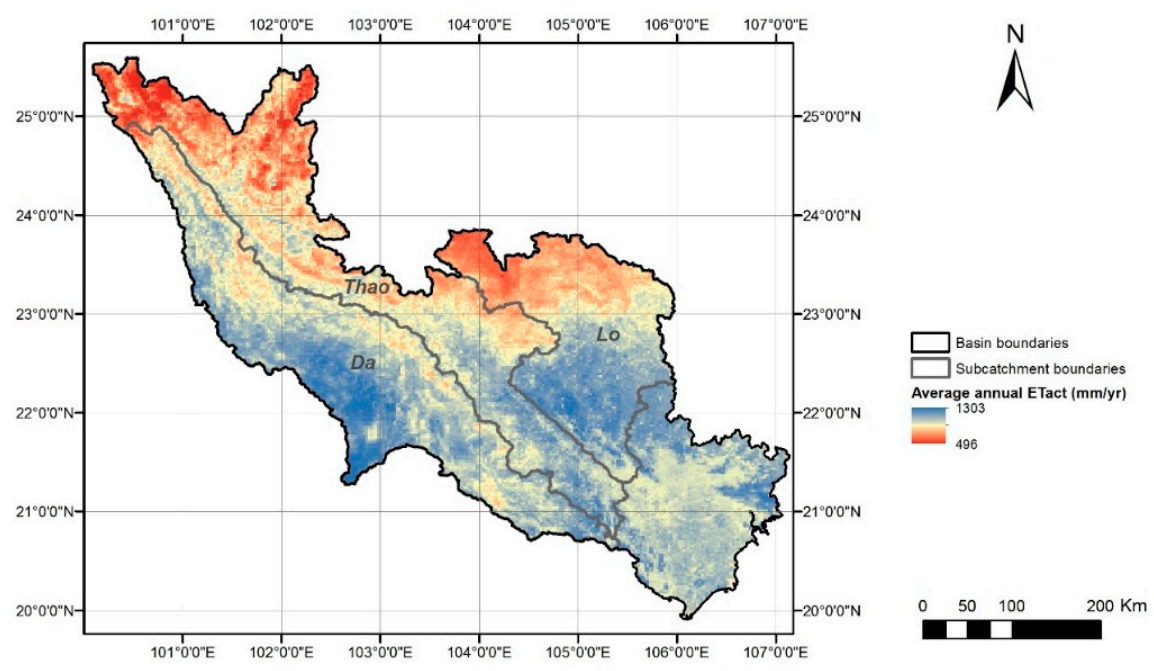

Figure 7. Annual $\mathrm{ET}_{\mathrm{act}}$ averaged in the Red River Basin for the period January 2003-December 2012.

\section{Results}

In this section, the ensemble-averaged ETact is used to study the water budget of the Red River basin. Long-term rainfall surplus is examined to determine the net production and consumption of water resources across the basin, in wet $v$ s. dry seasons, and per LULC class. Subsequently, monthly 
runoff patterns are investigated for each subcatchment and storage changes are expressed as a function of rainfall surplus.

\subsection{Rainfall Surplus}

Rainfall surplus $\left(\mathrm{P}_{\text {sur }}\right)$ can be viewed as the total water budget available for generating surface runoff, replenishing aquifers, or recharging soil moisture stores. The partitioning of $\mathrm{P}_{\text {sur }}$ among different hydrological processes depends on factors such as soil type, slope, and intensity of precipitation. For multi-annual time scales on which $\Delta \mathrm{S}$ can be neglected, $\mathrm{P}_{\text {sur }}$ equals the water yield $\left(\mathrm{P}-\mathrm{ET}_{\mathrm{act}}-\Delta \mathrm{S}\right)$, the comprehensive term that is transported downstream through surface and sub-surface pathways to constitute river flow.

Figure 8 presents the rainfall surplus in the Red River Basin for 2003-2012. From this map it can be concluded that the Red River Basin in a sense is an atypical river basin, with the upstream part generating relatively little runoff. Particularly the forested areas of the northern portion of the basin have a low $\mathrm{P}_{\text {sur }}$ over this ten-year period. Rainfall is lower here than in other parts of the basin, and forests likely grow deep roots to tap into aquifers. The highest $\mathrm{P}_{\text {sur }}$ occurs in the central part of the basin, a transitional area between the low-lying southeast and the mountainous north, with peak values of up to $1300 \mathrm{~mm}$ /year. From the perspective of transboundary water management, it is interesting to note that the majority of the average annual $\mathrm{P}_{\text {sur }}$ occurs in Vietnamese territories ( $825.4 \mathrm{~mm}$, or $\left.\sim 73,000 \mathrm{~km}^{3}\right)$, while only $390.3 \mathrm{~mm}\left(\sim 30,000 \mathrm{~km}^{3}\right)$ is produced in China.

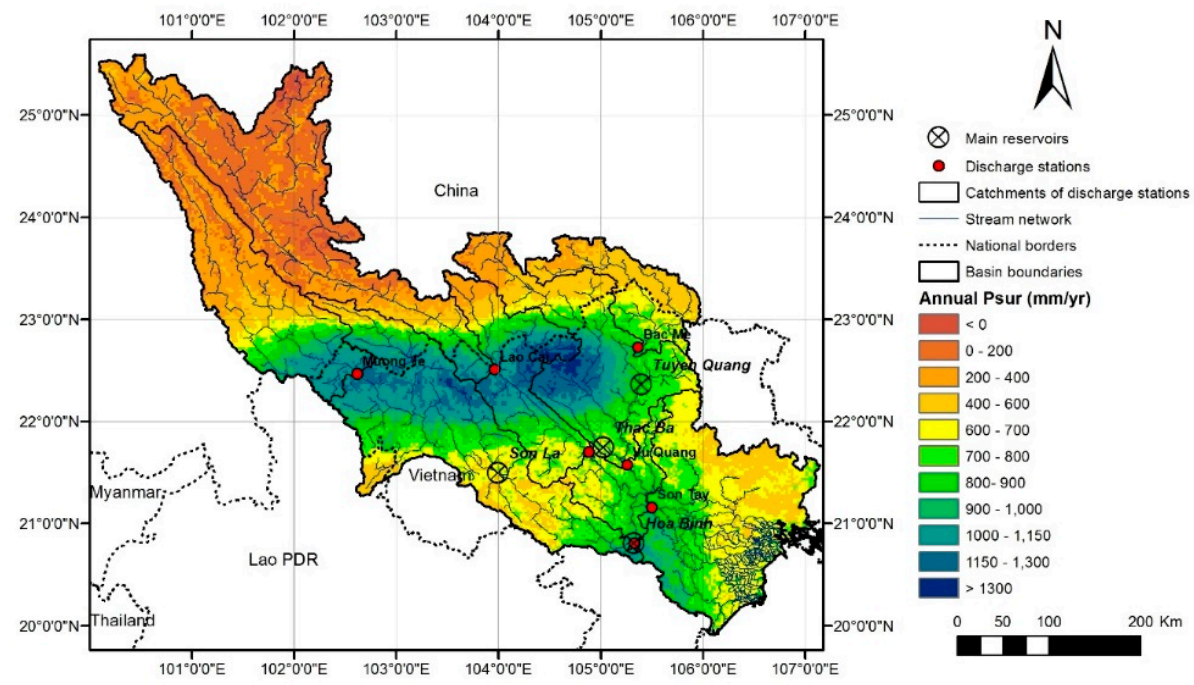

Figure 8. Map of annual average rainfall surplus in the Red River Basin based on January 2003-December 2012. Also indicated are the largest dams that provide opportunities for water storage. Hoa Binh and Thac Ba dam were operational during this entire period, Tuyen Quang and Son La dam were commissioned in 2008 and 2011, respectively.

Figure 8 shows that the irrigated Red River Delta on average does not consume water on the annual scale. This, however, is not the case when examining the irrigated spring rice season. Figure 9a shows how $\mathrm{P}_{\text {sur }}$ becomes negative due to water withdrawals during February-April 2010, when a net water consumption of up to $100 \mathrm{~mm}$ is observed in the delta. In general, a negative $\mathrm{P}_{\text {sur }}$ can be partially related to changes of water storage in the unsaturated zone, but a negative value during elongated periods is indicative of withdrawals. During the rainy summer season, $\mathrm{P}_{\text {sur }}$ is high in the entire basin (Figure 9b). Within the delta, $\mathrm{P}_{\text {sur }}$ is observed to be highest in the western part, where drainage is the most challenging due to the low relative altitude in relation to the water level [44]. 


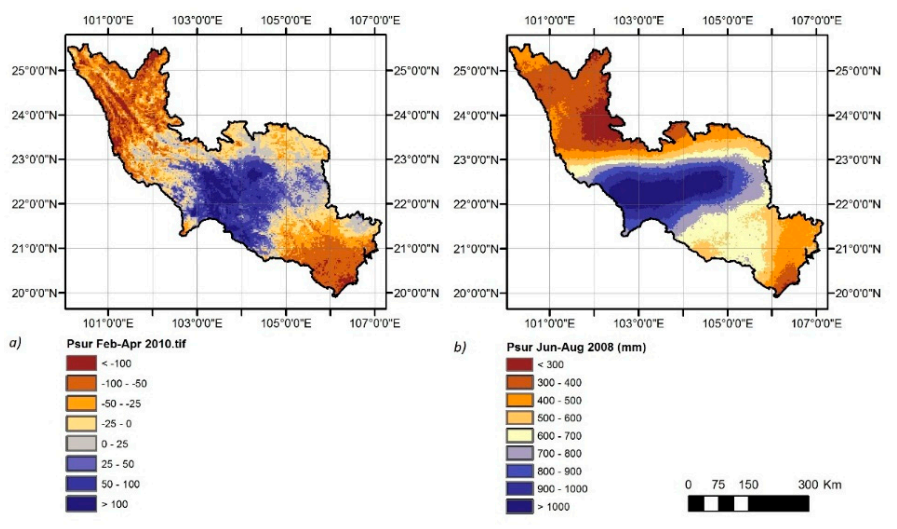

Figure 9. Rainfall surplus during February 2010-April 2010 (a) and June-August 2008 (b), respectively, the driest spring rice season and the wettest three-monthly period in the time series under consideration.

To evaluate water consumers and producers in the Red River Basin, the spatially distributed $P_{\text {sur }}$ assessment was coupled with the improved LULC map (Figure 3). Table 6 provides an overview of water consumption and production by the different LULC classes in the Red River Basin. It is found that, on average, there is no net water-consuming LULC class on the annual scale. The largest amount of water in the Red River basin is produced by the extensive forest and shrubland ecosystems (an annual total of $62.3 \mathrm{~km}^{3}$ ). In total, $102.6 \mathrm{~km}^{3}$ (or $621 \mathrm{~mm} /$ year) of water is produced on average per year, which can be viewed as an estimation of the total outflow of the complex stream network of the Red River Delta.

Table 6. Overview of consumptive use and water production per LULC class in the Red River Basin for the period 2003-2012.

\begin{tabular}{|c|c|c|c|c|c|c|c|c|}
\hline LULC Class & $\begin{array}{c}\text { Area } \\
\left(\mathrm{km}^{2}\right)\end{array}$ & $\begin{array}{c}P \\
\text { (mm/Year) }\end{array}$ & $\begin{array}{c}\mathbf{P} \\
\left(\mathrm{km}^{3} / \text { Year }\right)\end{array}$ & $\begin{array}{c}\text { ET }_{\text {act }} \\
(\mathrm{mm} / \text { Year })\end{array}$ & $\begin{array}{c}\mathrm{ET}_{\text {act }} \\
\left(\mathrm{km}^{3} / \text { Year }\right)\end{array}$ & $\begin{array}{c}\mu \mathbf{P}_{\text {sur }} \\
(\mathrm{mm} / \text { Year) }\end{array}$ & $\begin{array}{c}\sigma P_{\text {sur }} \\
(\mathrm{mm} / \text { Year })\end{array}$ & $\begin{array}{c}\text { Produced } \\
\left(\mathrm{km}^{3} / \text { Year }\right)\end{array}$ \\
\hline $\begin{array}{l}\text { Irrigated-double or } \\
\text { triple crop }\end{array}$ & $22,655.8$ & 1591.5 & 36.1 & 890.3 & 20.2 & 701.2 & 256.1 & 15.9 \\
\hline Rainfed-single crop & $18,898.5$ & 1175.1 & 22.2 & 736.8 & 13.9 & 438.4 & 261.2 & 8.3 \\
\hline $\begin{array}{l}\text { Mosaic vegetation } \\
\text { ( }<50 \% \text { cropland })\end{array}$ & $20,925.8$ & 1586.4 & 33.2 & 886.5 & 18.6 & 699.9 & 304.7 & 14.6 \\
\hline $\begin{array}{c}\text { Closed to open } \\
\text { broadleaved evergreen or } \\
\text { semi-deciduous forest }\end{array}$ & $32,431.4$ & 1601.6 & 51.9 & 948.7 & 30.8 & 652.9 & 345.1 & 21.2 \\
\hline $\begin{array}{l}\text { Closed broadleaved } \\
\text { deciduous forest }\end{array}$ & 1817.3 & 1534.1 & 2.8 & 860.2 & 1.6 & 674.0 & 363.6 & 1.2 \\
\hline $\begin{array}{l}\text { Open broadleaved } \\
\text { deciduous } \\
\text { forest/woodland }\end{array}$ & 4281.5 & 1411.3 & 6.0 & 880.6 & 3.8 & 530.7 & 349.3 & 2.3 \\
\hline $\begin{array}{c}\text { Open needleleaved } \\
\text { deciduous or } \\
\text { evergreen forest }\end{array}$ & $11,948.4$ & 1477.5 & 17.7 & 857.6 & 10.2 & 620.0 & 347.9 & 7.4 \\
\hline $\begin{array}{c}\text { Closed to open mixed } \\
\text { broadleaved and } \\
\text { needleleaved forest }\end{array}$ & 3460.1 & 1327.7 & 4.6 & 839.4 & 2.9 & 488.3 & 299.2 & 1.7 \\
\hline Closed to open shrubland & $46,406.2$ & 1522.5 & 70.7 & 913.4 & 42.4 & 609.1 & 338.4 & 28.3 \\
\hline $\begin{array}{c}\text { Closed to open } \\
\text { herbaceous vegetation }\end{array}$ & 396.5 & 1633.3 & 0.6 & 958.1 & 0.4 & 675.2 & 180.7 & 0.3 \\
\hline Urban areas & 593.6 & 1618.4 & 1.0 & 852.5 & 0.5 & 765.9 & 168.3 & 0.5 \\
\hline Total & $165,178.1$ & & 249.1 & & 146.4 & & & 102.6 \\
\hline
\end{tabular}

One of the most striking findings from this analysis is that a relatively large amount of water is produced by areas classified as irrigated cropland, while the opposite is found for the single-cropped rainfed class. Although this may be counterintuitive, it is caused by the geographical concentration of 
single crop agriculture in areas with a relatively low annual rainfall $( \pm 1000-1300 \mathrm{~mm})$. It is observed that the areas equipped with irrigation infrastructure (particularly the delta) are generally receiving more rainfall from the Tonkin sea during the rainy season than the zones dominated by rainfed agriculture further land inwards. Therefore, the observed higher $\mathrm{ET}_{\text {act }}$ in double- or triple-cropped systems ( $890.3 \mathrm{~mm}$ /year vs. $736.8 \mathrm{~mm}$ /year) does not lead to a lower rainfall surplus compared to single crop agriculture. This very high summer rainfall in the delta is a known phenomenon, and the different tributaries and canals essentially serve as drainage canals during this period [80].

\subsection{Runoff Response Patterns and Storage Changes}

When considering time scales of a single year or smaller, the change in storage $\Delta S$ becomes an essential component of the water balance. By relating the measured $Q$ from different gauging stations to upstream $\mathrm{P}_{\text {sur, }}$ it is possible to e.g., identify the locations within a river basin where most streamflow originates, and the time periods when water stores in the soil profile and aquifers are replenished.

For different sections of the Red River Basin, measured streamflow and satellite-derived $\mathrm{P}_{\text {sur }}$ are compared in Figure 10. In the rainy season, streamflow from the catchments of all available stations typically lags behind the increase in $\mathrm{P}_{\text {sur }}$ by 1 to 2 months, while the decline in both parameters around September occurs simultaneously. This is likely caused by water storage in aquifers and the soil profile, occurring up to the point of saturation after which all $\mathrm{P}_{\text {sur }}$ will be discharged as surface runoff. River discharge in parts of the Red River Basin is largely managed, as several large man-made reservoirs are present aimed at flood buffering and hydropower generation [81]. Dry season flow is highest at Hoa Binh and $\mathrm{Vu}$ Quang, where artificial storage capacity in the upstream catchments is largest.

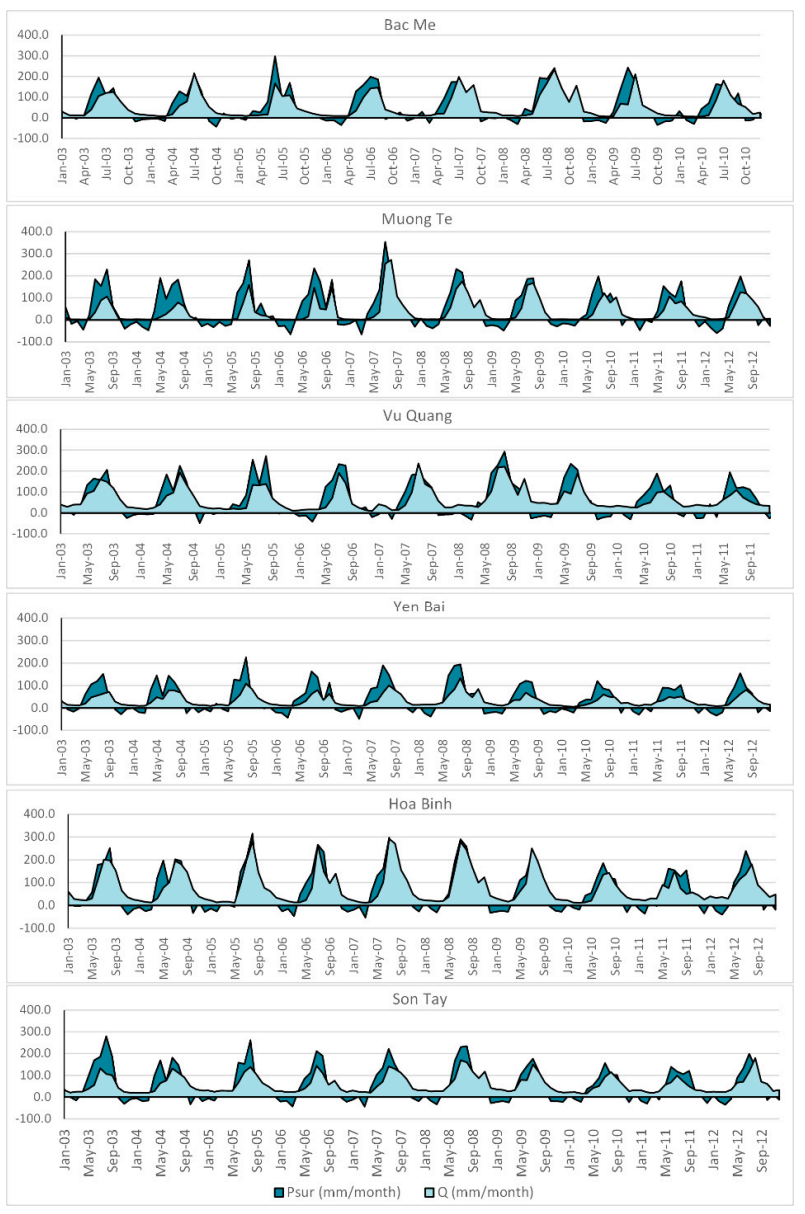

Figure 10. Graphs of upstream rainfall surplus $\left(\mathrm{P}_{\text {sur }}\right)$ from remote sensing and measured streamflow (Q) for each of the available discharge stations. 
Table 7 lists the long-term $\mathrm{Q} / \mathrm{P}_{\text {sur }}$ values for each of the catchments. Some values deviate substantially from 100\%, which indicates that the 2003-2012 $\Delta$ S term may not be negligible for these areas. The low 10 -year average of $80.9 \%$ for Muong Te can be explained by the construction of several dams in the Chinese part of the Da basin. In previous work [82], at least nine hydropower reservoirs were identified that were commissioned in the years 2007-2009. The filling of these reservoirs in the preceding years has caused an average $Q / \mathrm{P}_{\text {sur }}$ of $56.1 \%$ until March 2007, whereas for April 2007 till September 2012 a value of 99\% is found, indicating an almost perfect closure of the water balance by satellite-derived $P_{\text {sur. }}$. The total volume of water stored in the new Chinese reservoirs in Da River and its tributaries between April 2003 and March 2007 is estimated at $22.7 \mathrm{~km}^{3}$. Another interesting finding is that annual $\mathrm{Q} / \mathrm{P}_{\text {sur }}$ values for the Hoa Binh catchment continuously exceed $100 \%$, whereas the opposite is observed for the adjacent Yen Bai catchment. In combination with the satisfactory agreement between $\mathrm{P}, \mathrm{ET}_{\text {act }}$ and $\mathrm{Q}$ data in other catchments, and in the absence of any notable interbasin transfers (to our knowledge), this phenomenon may be partly explained by groundwater flow from the Thao basin to the Da basin.

Table 7. Comparison of streamflow $Q$ and rainfall surplus $P_{\text {sur }}$ for each catchment, with slopes and $R^{2}$ for linear relationships between monthly $Q$ and upstream $P_{\text {sur. }}$. Also given are the values of $Q / P_{\text {sur }}$ during the rainy season. All values represent the 2003-2012 period.

\begin{tabular}{|c|c|c|c|c|c|c|c|c|}
\hline \multirow{2}{*}{ Station } & \multirow{2}{*}{$\mathrm{Q} / \mathrm{P}_{\text {sur }}(\%)$} & \multirow{2}{*}{$\mathrm{Q} / \mathrm{P}_{\text {sur }}$ Slope $(-)$} & \multirow{2}{*}{$\mathbf{R}^{2}$} & \multicolumn{5}{|c|}{ Monsoonal $Q / P_{\text {sur }}$} \\
\hline & & & & May & June & July & August & September \\
\hline Bac Me & 98.4 & 0.60 & 0.66 & 0.37 & 0.55 & 1.07 & 1.78 & 1.68 \\
\hline Muong Te & 80.9 & 0.49 & 0.61 & 0.15 & 0.28 & 0.61 & 0.80 & 1.03 \\
\hline Vu Quang & 101.0 & 0.50 & 0.67 & 0.71 & 0.54 & 0.91 & 0.86 & 1.57 \\
\hline Yen Bai & 87.2 & 0.33 & 0.65 & 0.52 & 0.43 & 0.45 & 0.61 & 1.39 \\
\hline Hoa Binh & 125.9 & 0.65 & 0.72 & 0.59 & 0.71 & 0.94 & 0.98 & 2.21 \\
\hline Son Tay & 107.2 & 0.43 & 0.71 & 0.74 & 0.56 & 0.71 & 0.79 & 1.43 \\
\hline
\end{tabular}

To compare monthly $Q$ and $P_{\text {sur }}$, Table 7 lists the slope and $\mathrm{R}^{2}$ obtained from linear regression between both variables. For the entire gauged portion of the Red River Basin (upstream of Son Tay), $43 \%$ of rainfall surplus is converted to surface runoff. The highest $Q / P_{\text {sur }}$ value of 0.65 is found for Hoa Binh catchment, whereas only $33 \%$ of $\mathrm{P}_{\text {sur }}$ contributes to surface runoff upstream of Yen Bai. A reason for this difference is likely the catchment topography, with a lower average slope in the upstream catchent of the latter station. In addition, average annual $\mathrm{P}_{\text {sur }}$ is substantially higher in Hoa Binh with $730 \mathrm{~mm}$ as opposed to $460 \mathrm{~mm}$ for Yen Bai, increasing the frequency of occurrence of saturated conditions in the soil profile.

Although the multi-annual $\mathrm{Q}$ and $\mathrm{P}_{\text {sur }}$ are congruent at the subcatchment scale, it is not obvious that a correlation on the monthly scale should be expected. Especially in dry months when the catchment storage is relatively empty, a low and stable $Q$ is observed (likely driven by baseflow) that is not significantly affected by variability in monthly $\mathrm{P}_{\text {sur }}$. During wet months, however, the progression of the $\mathrm{Q} / \mathrm{P}_{\text {sur }}$ ratio is representative of the changing response of the catchment to rainfall. Table 7 lists average $\mathrm{Q} / \mathrm{P}_{\text {sur }}$ for each of the months in the rainy season. A similar pattern is observed for all catchments, in which the ratio increases as the rainy season progresses and exceeds 1 at the end of monsoon in September. This consistent increase of $Q / P_{\text {sur }}$ suggests that in the Red River Basin saturation excess processes are dominant in runoff generation, rather than Hortonian runoff occurring during high-intensity precipitation events $[83,84]$. Monthly $Q / P_{\text {sur }}$ values substantially higher than 1 could occur due to groundwater flow between catchments, or human actions; e.g. when large volumes of water are released from the reservoirs. These releases occur in particular during the monsoonal months, when flood buffering capacity is required and a maximum water level is maintained [85]. Although these management actions are expected to affect $\mathrm{Q} / \mathrm{P}_{\text {sur }}$, the natural processes of streamflow generation still appear clearly in the figures in Table 7. 
As correlation between $\mathrm{Q}$ and $\mathrm{P}_{\text {sur }}$ is logically weak for specific months, it is not yet feasible to predict $Q$ for every month solely from remote sensing. This could change when $\mathrm{ET}_{\text {act }}$ GSDPs come available on a daily basis, which will enable a detailed investigation of the relation between cumulative $\mathrm{P}_{\text {sur }}$ from the start of the hydrological year and the $Q / \mathrm{P}_{\text {sur }}$ term [84]. However, a clear relation is observed between monthly $\mathrm{P}_{\text {sur }}$ and $\Delta S$, as the storage capacity of the Red River Basin is not fully satisfied for the major part of the year. Therefore, it is possible to express volumetric $\Delta S$ as a function of remotely sensed $\mathrm{P}_{\text {sur. }}$. Figure 11 depicts a plot of monthly $\Delta \mathrm{S} v s . \mathrm{P}_{\text {sur, }}$ upstream of Son Tay. A clockwise hysteresis pattern can be observed. Linear models were derived that enable the prediction of $\Delta S$ without the need for ground observations. From December until the start of the rainy season in April, the slope of the models is near to 1 with a relatively stable intercept in the order of 23-29 mm, which can be viewed as the contribution of groundwater to streamflow. The slope of the model decreases as storage fills up and the contribution of $\mathrm{P}_{\text {sur }}$ to $\mathrm{Q}$ increases. As $\mathrm{P}_{\text {sur }}$ values decrease in September and October due to declining rainfall, the low intercept is representative of the rainwater from previous months that is now taken out of storage to contribute to streamflow. Errors in the derived models for monsoonal months are partly caused by human interventions in Red River water management, and this approach is expected to work even better in more "natural" river basins.

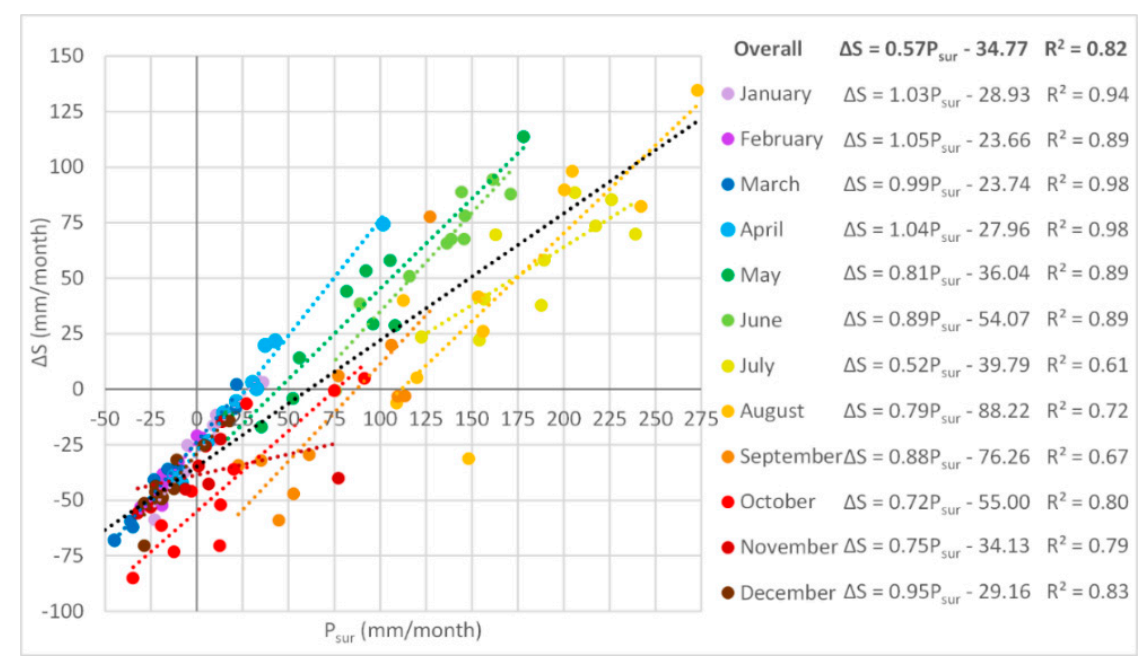

Figure 11. Monthly changes in storage upstream of Son Tay station $(\Delta S)$ plotted against the rainfall surplus $\left(\mathrm{P}_{\text {sur }}\right)$. Dashed lines indicate the lines of best fit for each month (colored) and the entire year (black). For each month, the derived linear model is given on the right with its respective coefficient of determination $\left(\mathrm{R}^{2}\right)$.

\section{Discussion}

With the increasing availability of global actual evapotranspiration data in the public domain, in addition to rainfall and land use/land cover, it is now possible to quantify the main components of the water balance for river basins in a distributed manner. This paper shows that rainfall surplus can be successfully computed from global satellite-derived data products for monthly, annual and multi-annual time scales. The total annual water yield of $102.6 \mathrm{~km}^{3}$ computed for the entire Red River Basin is an estimation of long-term river outflow, which is especially valuable because of the lack of streamflow gauges in the Red River Delta [75]. In non-saturated conditions, spatially distributed monthly $\mathrm{P}_{\text {sur }}$ is strongly related to changes in storage, and monthly $\Delta \mathrm{S}$ can thus be quantitatively determined from satellite data. These findings demonstrate that assessments of rainfall surplus from satellite-derived $\mathrm{P}$ and $\mathrm{ET}_{\text {act }}$ potentially facilitate sound water accounting in ungauged river basins that was previously impossible due to missing ground data.

It was found that the SSEBop $\mathrm{ET}_{\text {act }}$ product succeeds in closing the water balance of the Red River Basin with respect to TRMM rainfall and longer-term streamflow records, while the other products 
seem to have a tendency to overestimate $\mathrm{ET}_{\mathrm{act}}$. The range of average annual $\mathrm{ET}_{\text {act }}$ values according to different products is found to be rather large $(268 \mathrm{~mm} /$ year) and illustrates the need for a thorough comparison. For areas with frequent cloud cover, a part of this range is likely attributed to the various ways in which the $\mathrm{ET}_{\text {act }}$ algorithms deal with cloud-covered skies and data gaps. The observed difference between the individual models is somewhat inconsistent with the very low errors in satellite-derived $\mathrm{ET}_{\mathrm{act}}$ that were found in the review by Karimi and Bastiaanssen [12], which illustrates the current disparity between region-specific $\mathrm{ET}_{\text {act }}$ estimate with opportunities for parameter-tuning and extractions from global datasets. It was found that for the Red River Basin spatial patterns of MOD16, SSEBop and ALEXI are similar, and this finding has been used to compute the areal $\mathrm{ET}_{\mathrm{act}}$ patterns from these three $\mathrm{ET}_{\text {act }}$ products with equal weight. The fundamental differences between a relatively simple, largely LST-based model (SSEBop), an algorithm with more advanced physics incorporating temporal LST variability and a separation between evaporation and transpiration (ALEXI), and a method strongly reliant on LAI (MOD16), support the assumption that the selected models complement each other in terms of performance over a heterogeneous terrain. The consistency between satellite-derived $P_{\text {sur }}$ and measured $Q$ in terms of both inter- and intra-annual variability, as well as their agreement for individual subcatchments, put confidence in the constructed ensemble ET $_{\text {act }}$ maps.

Previous studies in other basins have yielded differing outcomes regarding the relative performance of the respective $\mathrm{ET}_{\mathrm{act}}$ algorithms. Therefore, the appropriate choice of models for basin-scale normalization is expected to vary from basin to basin. In future studies, depending on the properties of the river basin at hand, different types of ensemble products may be suitable. It is advised that future research focuses on reviewing the strengths and weaknesses of the ET $\mathrm{act}_{\mathrm{a}}$ GSDPs with respect to different LULC types and climate zones, with the aim to achieve a reliable satellite-derived $\mathrm{ET}_{\text {act }}$ estimation on the global scale. When doing so, the uncertainties associated with each of the components of the water balance, including streamflow records, should receive sufficient attention. It should be noted that the $\mathrm{ET}_{\text {act }}$ products applied in this research are in differing stages of development and substantial progress is to be expected in the next few years. For example, future versions of the ALEXI product will implement microwave-based LST [86] to provide estimates of ET $_{\text {act }}$ over all-sky conditions which is particularly important over the Red River basin during persistently cloudy periods. This use of microwave LST will help constrain estimates of $\mathrm{ET}_{\text {act }}$ during such periods, which currently rely on gap-filling techniques with high uncertainty and are likely responsible for some of the overestimation of $\mathrm{ET}_{\text {act }}$ seen in this study.

Analyses of global remote sensing products provide a valuable first outlook on the main hydrological processes within a river basin, especially after verification against the longer term total river outflow to ensure mass balance and consistency. Hydrological models are capable of providing complementary information, for example on non-linear sub-soil flow processes that determine runoff, infiltration, storage change, percolation and recharge. These processes govern the partitioning of rainfall surplus into groundwater and surface water. Models also facilitate analyses on a daily time scale, for which only a few $\mathrm{ET}_{\text {act }}$ GSDPs are currently available. It is already common practice to use satellite-derived information, in particular P and LULC, as inputs to hydrological models. However, results of remote sensing-based quantifications of monthly $\mathrm{ET}_{\mathrm{act}}, \mathrm{P}_{\text {sur }}$ and $\Delta S$, as well as multi-annual $\mathrm{Q}$ can also be used to train and constrain hydrological models and water management decision tools. Examples are already available in which remotely sensed $\mathrm{ET}_{\text {act }}$ is used to constrain hydrological models, or for calibration purposes [87-93]. P minus $\mathrm{ET}_{\text {act }}$ appears to be highly correlated with the root zone storage capacity [36]. By using satellite-derived information as a reality check, model performance can be improved. This is in particular relevant in areas with abundant water withdrawals, which require a lot of assumptions to simulate but are implicitly included in remotely sensed $\mathrm{ET}_{\text {act }}$ [94].

Currently, much attention goes out to the development of global hydrological models (GHMs). Several reviews of the current state of art were recently published [95-97]. There are even ongoing attempts to create the first operational, hyper-resolution GHM [98]. Integration with remote sensing is 
identified as one of the promising trends in GHMs to reduce uncertainties [97]. The latest generation of GHMs is capable of spatially explicit assessments of the consumed fraction of applied irrigation water, thus no longer requiring an estimate of efficiencies as input [99,100]. However, these models still quantify water withdrawals for irrigation by supplying water until optimal growing conditions are achieved, an approach that is likely to lead to an overestimation of withdrawals [101]. Alternatively, non-physically based statistical methods are used to quantify water withdrawals for different water using sectors $[102,103]$. With $\mathrm{ET}_{\text {act }}$ maps now readily available on the global scale, it is a logical next step to start incorporating these products in GHMs, either as model constraints or in the calibration procedure. This could lead to a more realistic representation of withdrawals [101,104,105], and therefore of non-consumed water and reuse.

\section{Conclusions}

This paper demonstrates how an integration of readily available global satellite-derived data products can shed light on river basin hydrology. With the availability of rainfall (P), land use/land cover (LULC) and the newly available actual evapotranspiration ( $\left.\mathrm{ET}_{\mathrm{act}}\right)$ data on the global scale, such analyses can now be performed for all river basins as pre-analyses to numerical hydrology studies. The consistency between different $\mathrm{P}$ and $\mathrm{ET}_{\text {act }}$ products and downstream river discharge should first be evaluated by applying the law of mass conservation on the multi-annual scale. Even for a challenging basin in terms of atmospheric conditions such as the Red River Basin, satisfactory and meaningful conclusions were drawn. Based of $102.6 \mathrm{~km}^{3}$, of which only $29 \%$ is generated in China. Forests are the main water producer, while also irrigated cropland does not consume water on the annual scale. In addition, it proved possible to model monthly storage changes solely based on satellite derived $\mathrm{P}$ and $\mathrm{ET}_{\text {act }}$. The ratio of streamflow $(\mathrm{Q})$ over rainfall surplus $\left(\mathrm{P}_{\text {sur }}\right)$ was found to increase steadily during the rainy season, signifying the importance of saturation excess processes in runoff generation. This is a first step into determining the partitioning between fast surface runoff and slow groundwater runoff.

Although our comparison for the Red River shows that the range between values of individual evapotranspiration products is still substantial, it is concluded that there is a large potential for applying monthly remotely sensed $\mathrm{ET}_{\mathrm{act}}, \mathrm{P}_{\text {sur }}$, storage changes and multi-annual $\mathrm{Q}$ to constrain or calibrate hydrological models. This facilitates quantification of hydrological processes that take place on the daily or weekly time scale, or processes that cannot be assessed by remote sensing alone, such as withdrawals, non-consumed water and reuse. Further studies are required to examine the performance of the $\mathrm{ET}_{\text {act }}$ products for different geographical regions, climate zones and land use types, in order to ultimately facilitate the coupling between these products and global hydrological models. In the meantime, it is concluded that the proposed methodology based on spatial correlations among individual $\mathrm{ET}_{\mathrm{act}}$ products and absolute calibration of longer-term $\mathrm{P}-\mathrm{Q}$ works well for the conditions encountered in the Red River basin.

Acknowledgments: Part of this research was funded by the CGIAR Water Land and Ecosystems (WLE) MK27 program. Funds for publishing in open access were provided by the Open Access Fund of Delft University of Technology. The authors are grateful to the following persons and institutes for making available the global ET $_{\text {act }}$ products: Albert van Dijk (University of Australia), Juan Pablo Guerschman (CSIRO) and Jorge Pena Arancibia (CSIRO) for CMRSET, and Xuelong Chen (ITC) for SEBS. Hydrometeorological data were acquired in the framework of the project Demonstration of Remote Sensing Information for Integrated Reservoir Management in the Red River Basin in Northern Vietnam, funded by the Government of The Netherlands. The authors are thankful to Dung Duc Le and Duc Anh Nguyen of VINWATER for their assistance in acquiring, processing and interpreting the hydrometeorological data, and to Lan Thanh Ha of IWRP for his valuable inputs.

Author Contributions: G.W.H. Simons and W.G.M. Bastiaanssen conceived and designed the research; G.W.H. Simons analyzed the data; G.W.H. Simons and W.G.M. Bastiaanssen wrote the paper with valuable inputs from L. A. Ngo regarding regional the hydrological context and interpretation of results; and C.R. Hain, M.C. Anderson and G.B. Senay contributed to algorithm development, processing of $\mathrm{ET}_{\mathrm{act}}$ data, and data quality analysis.

Conflicts of Interest: The authors declare no conflict of interest. 
Appendix A. Rainfall Data

Table A1. Metadata of rainfall stations.

\begin{tabular}{|c|c|c|c|c|c|c|}
\hline & Station Name & Latitude & Longitude & Country & Elevation (m) & Source \\
\hline 1 & $\mathrm{Ba} \mathrm{Vi}$ & 21.10 & 105.43 & Vietnam & 20 & $\mathrm{NCHMF}$ \\
\hline 2 & Bac Can & 22.15 & 105.83 & Vietnam & 176 & GSOD \\
\hline 3 & Вас На & 22.53 & 104.28 & Vietnam & 107 & NCHMF \\
\hline 4 & $\mathrm{Bac} \mathrm{Me}$ & 22.73 & 105.37 & Vietnam & 380 & NCHMF \\
\hline 5 & Bac Quang & 22.50 & 104.87 & Vietnam & & NCHMF \\
\hline 6 & Bac Yen & 21.25 & 104.42 & Vietnam & 65 & NCHMF \\
\hline 7 & Ban Cung & 20.75 & 105.05 & Vietnam & & NCHMF \\
\hline 8 & Bao Lac & 22.95 & 105.67 & Vietnam & 283 & NCHMF \\
\hline 9 & Binh Lu & 22.37 & 103.61 & Vietnam & 636 & $\mathrm{NCHMF}$ \\
\hline 10 & Bounneua & 21.63 & 101.88 & Lao PDR & 923 & GSOD \\
\hline 11 & Cao Bang & 22.67 & 106.25 & Vietnam & 260 & GSOD \\
\hline 12 & Chiem Hoa & 22.15 & 105.27 & Vietnam & 56 & NCHMF \\
\hline 13 & Cho Ra & 22.45 & 105.72 & Vietnam & 210 & NCHMF \\
\hline 14 & Chuxiong & 25.02 & 101.52 & China & 1773 & GSOD \\
\hline 15 & Co Noi & 21.13 & 104.15 & Vietnam & 704 & $\mathrm{NCHMF}$ \\
\hline 16 & Cuc Phuong & 20.23 & 105.72 & Vietnam & & NCHMF \\
\hline 17 & Dali & 25.70 & 100.18 & China & 1992 & GSOD \\
\hline 18 & Dien Bien & 21.35 & 103.00 & Vietnam & & NCHMF \\
\hline 19 & Dinh Hoa & 21.90 & 105.63 & Vietnam & & $\mathrm{NCHMF}$ \\
\hline 20 & Guangnan & 24.07 & 105.07 & China & 1251 & GSOD \\
\hline 21 & Ha Dong & 20.97 & 105.77 & Vietnam & 8 & NCHMF \\
\hline 22 & Ha Giang & 22.82 & 104.97 & Vietnam & 113 & $\mathrm{NCHMF}$ \\
\hline 23 & Ha Noi ${ }^{\circ}$ & 21.02 & 105.80 & Vietnam & 6 & NCHMF \\
\hline 24 & Ham Yen & 22.07 & 105.03 & Vietnam & 54 & NCHMF \\
\hline 25 & Hoa Binh & 20.82 & 105.33 & Vietnam & 23 & NCHMF \\
\hline 26 & Hoang Su Phi & 22.75 & 104.68 & Vietnam & & NCHMF \\
\hline 27 & Jiangcheng & 22.62 & 101.82 & China & 1121 & GSOD \\
\hline 28 & Lai Chau & 22.05 & 103.15 & Vietnam & 244 & $\mathrm{NCHMF}$ \\
\hline 29 & Lang Son & 21.83 & 106.77 & Vietnam & 258 & GSOD \\
\hline 30 & Lao Cai & 22.50 & 103.97 & Vietnam & 112 & NCHMF \\
\hline 31 & Lincang & 23.95 & 100.22 & China & 1503 & GSOD \\
\hline 32 & Longzhou & 22.37 & 106.75 & China & 129 & GSOD \\
\hline 33 & Luy Cen & 22.58 & 104.40 & Vietnam & 133 & NCHMF \\
\hline 34 & Mai Chau & 20.65 & 105.05 & Vietnam & 160 & NCHMF \\
\hline 35 & Mengzi & 23.38 & 103.38 & China & 1302 & GSOD \\
\hline 36 & Moc Chau & 20.83 & 104.68 & Vietnam & 958 & NCHMF \\
\hline 37 & Mu Cang Chai & 21.85 & 104.08 & Vietnam & 975 & NCHMF \\
\hline 38 & Muong Cha & 21.97 & 102.87 & Vietnam & 487 & NCHMF \\
\hline 39 & Muong Nhe & 22.18 & 102.45 & Vietnam & 500 & NCHMF \\
\hline 40 & Muong Te & 22.37 & 102.83 & Vietnam & 310 & $\mathrm{NCHMF}$ \\
\hline 41 & Nam Dinh & 20.43 & 106.15 & Vietnam & 3 & $\mathrm{NCHMF}$ \\
\hline 42 & Nam Giang & 22.26 & 103.17 & Vietnam & & NCHMF \\
\hline 43 & Nam Muc & 21.88 & 103.30 & Vietnam & 494 & NCHMF \\
\hline 44 & Napo & 23.30 & 105.95 & China & 794 & GSOD \\
\hline 45 & Nguyen Binh & 21.84 & 104.65 & Vietnam & & $\mathrm{NCHMF}$ \\
\hline 46 & Nho Quan & 20.32 & 105.75 & Vietnam & 12 & NCHMF \\
\hline 47 & Ninh Binh & 20.25 & 105.98 & Vietnam & 2 & $\mathrm{NCHMF}$ \\
\hline 48 & Phu Ho & 21.45 & 105.23 & Vietnam & & NCHMF \\
\hline 49 & Phu Lien & 20.80 & 106.63 & Vietnam & 119 & GSOD \\
\hline 50 & Phu Ly & 20.52 & 105.92 & Vietnam & 3 & NCHMF \\
\hline 51 & Phu Yen & 21.27 & 104.63 & Vietnam & 182 & NCHMF \\
\hline 52 & Quynh Nhai & 21.85 & 103.57 & Vietnam & 802 & NCHMF \\
\hline 53 & Sam Neua & 20.42 & 104.07 & Lao PDR & 1000 & GSOD \\
\hline 54 & Sapa & 22.35 & 103.82 & Vietnam & 1570 & $\mathrm{NCHMF}$ \\
\hline 55 & Simao & 22.77 & 100.98 & China & 1303 & GSOD \\
\hline 56 & Sin $\mathrm{Ho}$ & 22.37 & 103.23 & Vietnam & 1529 & NCHMF \\
\hline 57 & Son La & 21.33 & 103.90 & Vietnam & 676 & NCHMF \\
\hline 58 & Son Tay & 21.13 & 105.50 & Vietnam & 15 & NCHMF \\
\hline 59 & Tam Dao & 20.90 & 104.45 & Vietnam & & NCHMF \\
\hline 60 & Tam Duong & 22.42 & 103.48 & Vietnam & 900 & $\mathrm{NCHMF}$ \\
\hline 61 & Thai Nguyen & 21.60 & 105.83 & Vietnam & 32 & GSOD \\
\hline 62 & Than Uyen & 21.95 & 103.88 & Vietnam & & NCHMF \\
\hline 63 & Thanh Hoa & 19.80 & 105.78 & Vietnam & 7 & GSOD \\
\hline
\end{tabular}


Table A1. Cont.

\begin{tabular}{ccccccc}
\hline & Station Name & Latitude & Longitude & Country & Elevation $(\mathbf{m})$ & Source \\
\hline 64 & Thanh Son & 21.19 & 105.16 & Vietnam & 50 & NCHMF \\
65 & Thuan Chau & 21.43 & 103.68 & Vietnam & 652 & NCHMF \\
66 & Tuan Giao & 21.58 & 103.42 & Vietnam & 570 & NCHMF \\
67 & Tuyen Quang & 21.82 & 105.22 & Vietnam & 81 & NCHMF \\
68 & Van Chan & 22.05 & 104.15 & Vietnam & 257 & NCHMF \\
69 & Viengsay & 20.42 & 104.23 & Lao PDR & 913 & GSOD \\
70 & Viet Tri & 21.27 & 105.42 & Vietnam & 17 & NCHMF \\
71 & Vinh Yen & 22.27 & 104.88 & Vietnam & & NCHMF \\
72 & Wujiaba & 25.02 & 102.68 & China & 1892 & GSOD \\
73 & Yen Bai & 21.70 & 104.87 & Vietnam & & NCHMF \\
74 & Yen Chau & 21.07 & 104.27 & Vietnam & 59 & NCHMF \\
75 & Yuanjiang & 23.60 & 101.98 & China & 398 & GSOD \\
76 & Yuanmou & 25.73 & 101.87 & China & 1120 & GSOD \\
\hline
\end{tabular}

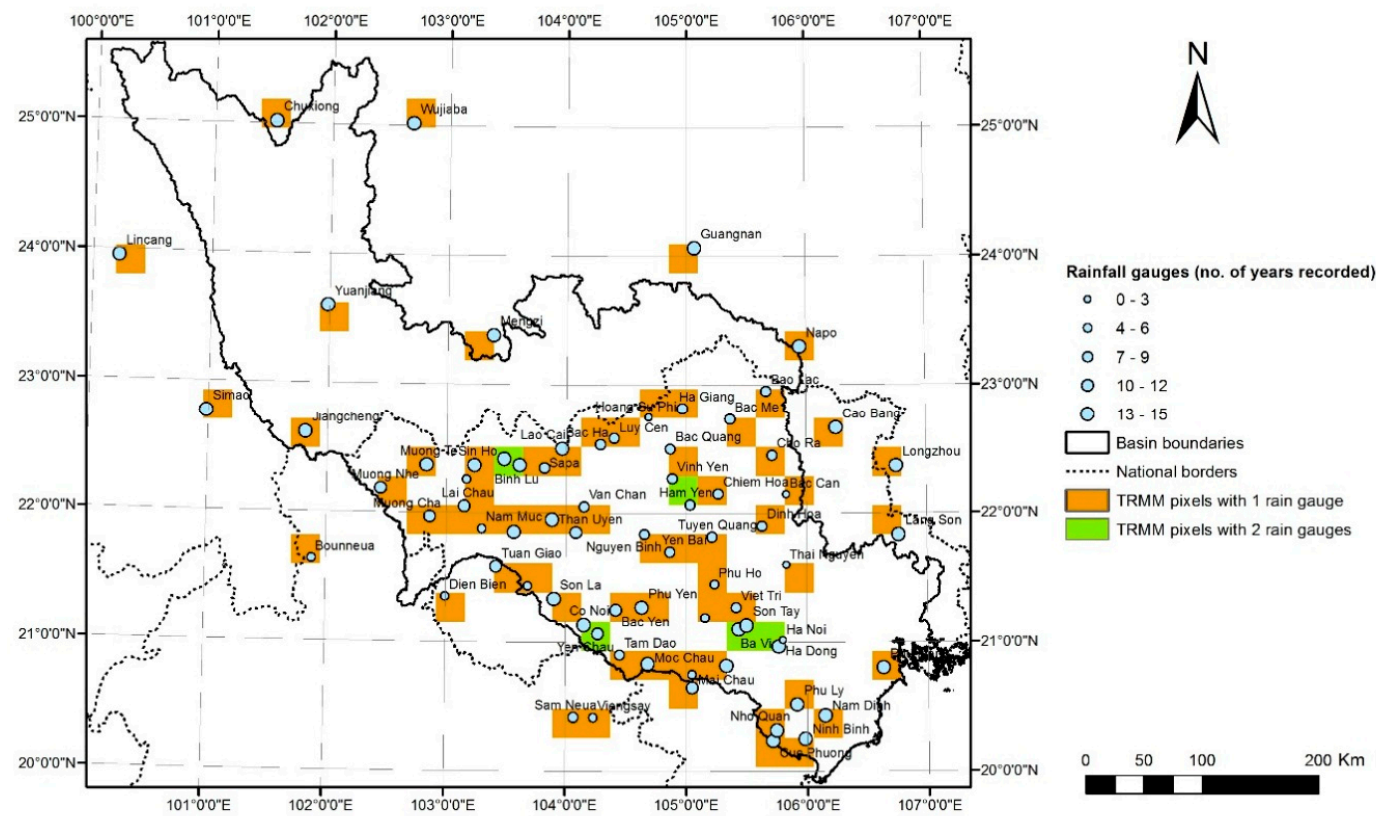

Figure A1. Spatial distribution of TRMM pixels with one (red) or two (green) rainfall gauges.

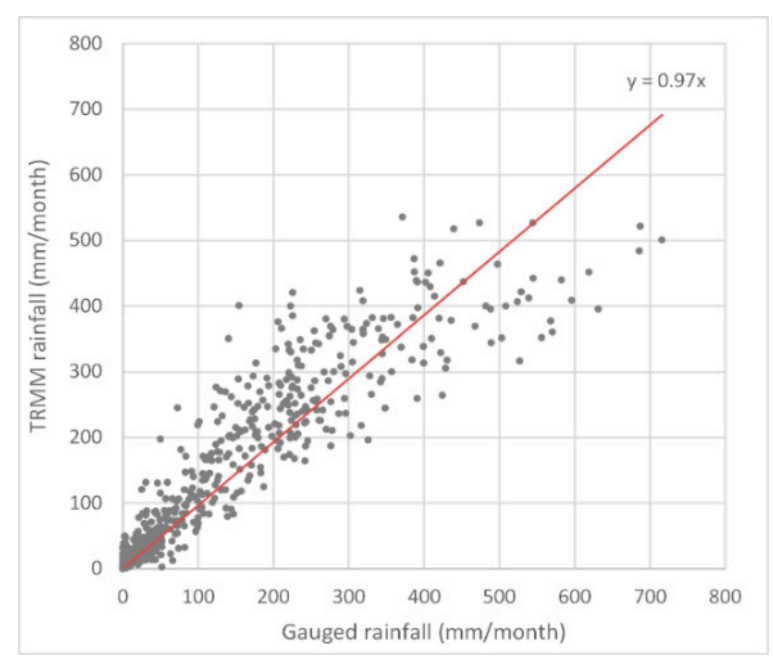

Figure A2. Comparison of TRMM data with measured monthly rainfall averaged per pixel for gauges in pixels with multiple stations. The red line gives the linear regression best fit with 0 intercept. 
Appendix B. Maps of Annual ETact in the Red River Basin (2003-2012)

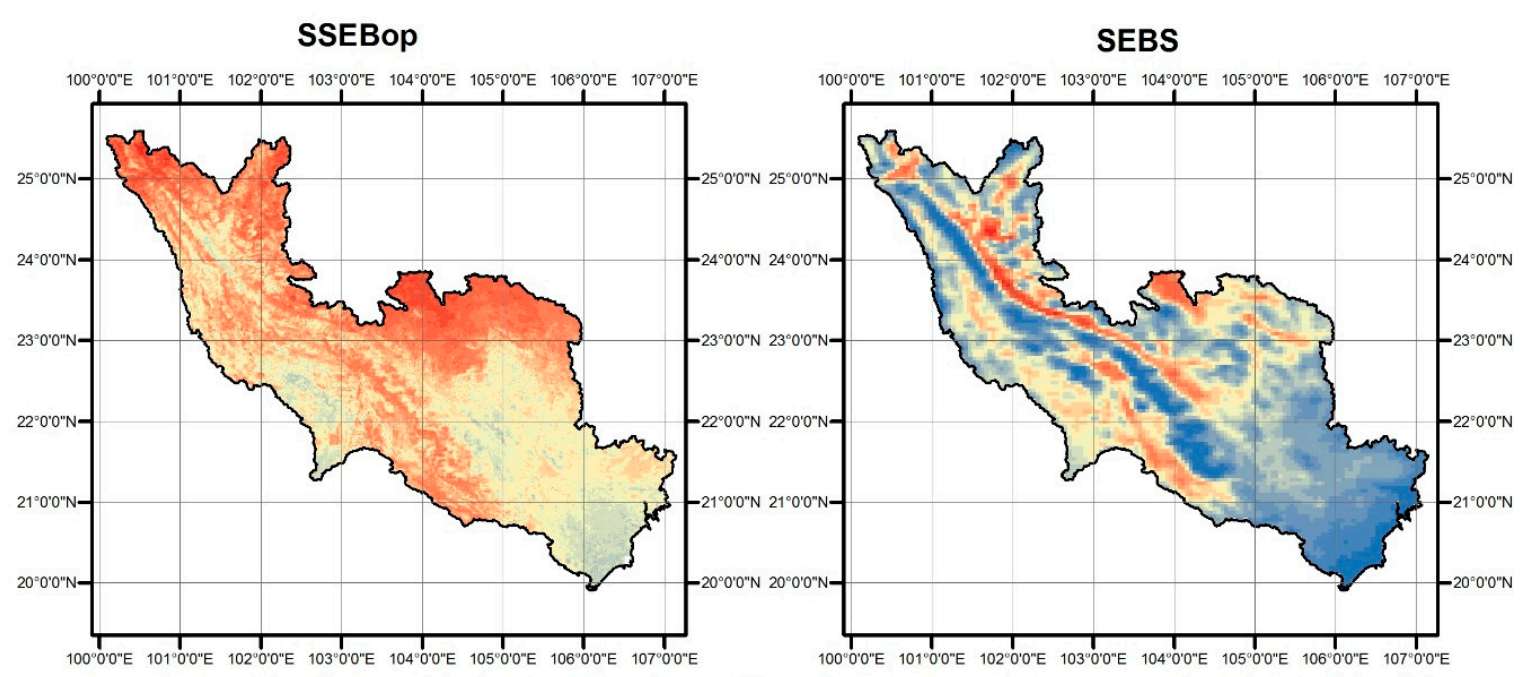

$\stackrel{N}{\Lambda}$

ALEXI

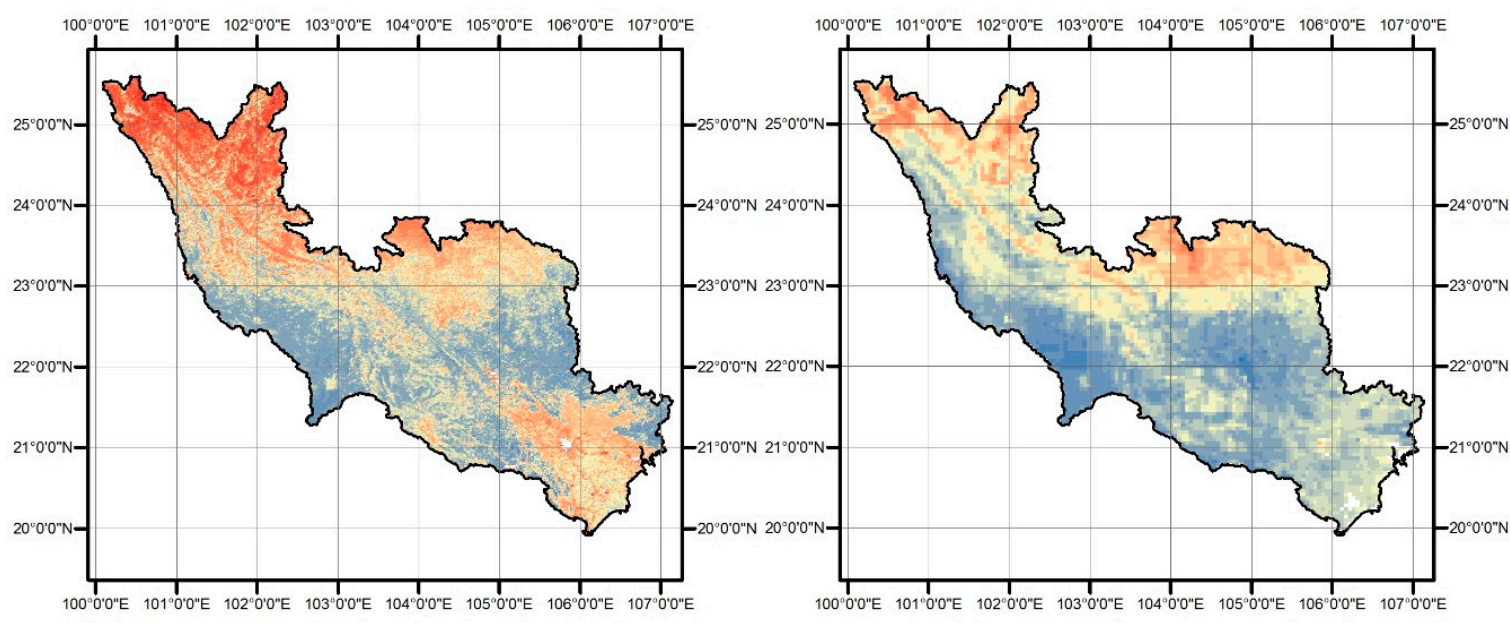

$\begin{array}{llll}\text { CMRSET } & 0 & 125 & 250 \\ & & & \end{array}$

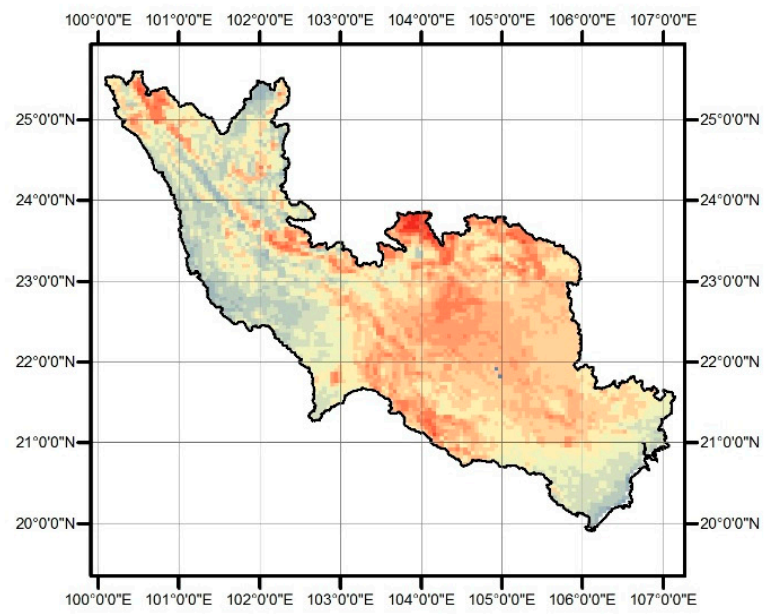

Annual ETact 2003-2012 (mm/yr)

$\longrightarrow<500$

$500-600$

$\square 00-700$

$700-800$

$\square 800-850$

$850-900$

$900-950$

$950-1,000$

1,000-1,050

$\square, 050-1,100$

$1,100-1,150$

$\square 1,150-1,200$

$1,200-1,300$

$1,300-1,400$

$1,400-1,500$

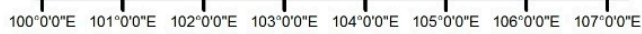

Figure A3. Overview of annual $\mathrm{ET}_{\mathrm{act}}$ in the Red River Basin according to five different GSDPs. 


\section{Appendix C. Coefficient of Variation in Annual Average ET act $_{\text {a }}$}

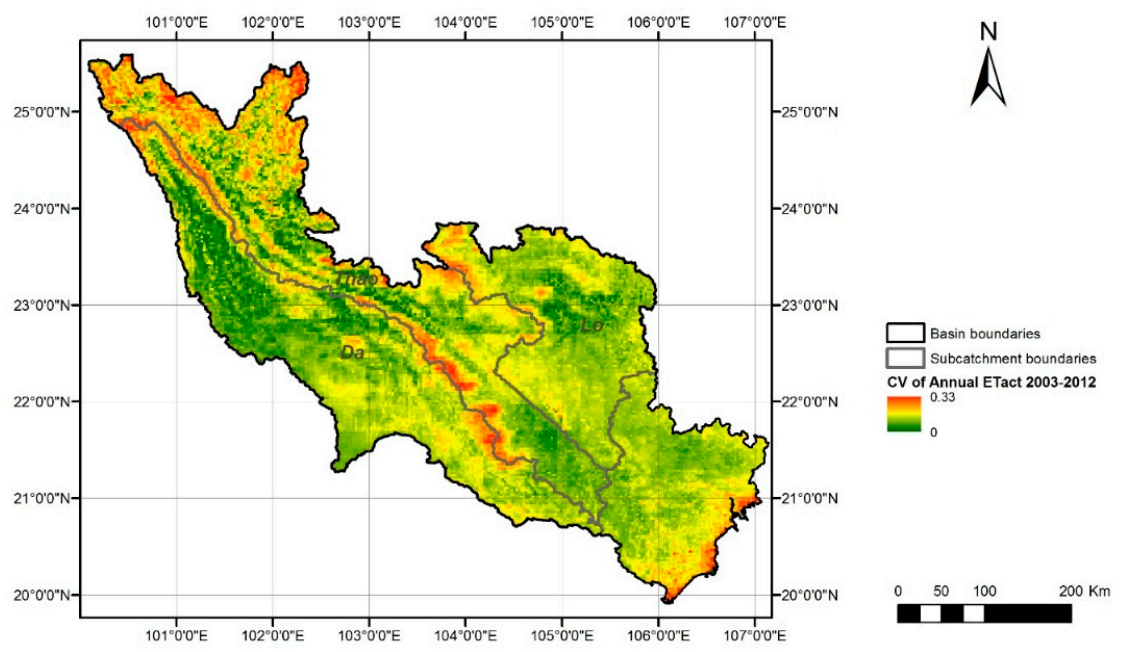

Figure A4. Map of the coefficient of variation (CV) of annual average $\mathrm{ET}_{\text {act }}$ based on five different products.

\section{Appendix D. Streamflow Data}

Table A2. Metadata of streamflow stations.

\begin{tabular}{lccccc}
\hline & Station Name & Latitude & Longitude & Country & Source \\
\hline 1 & Muong Te & 22.47 & 102.62 & Vietnam & NCHMF \\
2 & Hoa Binh & 20.81 & 105.32 & Vietnam & NCHMF \\
3 & Lao Cai & 22.50 & 103.95 & Vietnam & NCHMF \\
4 & Yen Bai & 21.70 & 104.88 & Vietnam & NCHMF \\
5 & Bac Me & 22.73 & 105.37 & Vietnam & NCHMF \\
6 & Vu Quang & 21.57 & 105.25 & Vietnam & NCHMF \\
7 & Son Tay & 21.15 & 105.50 & Vietnam & NCHMF \\
\hline
\end{tabular}
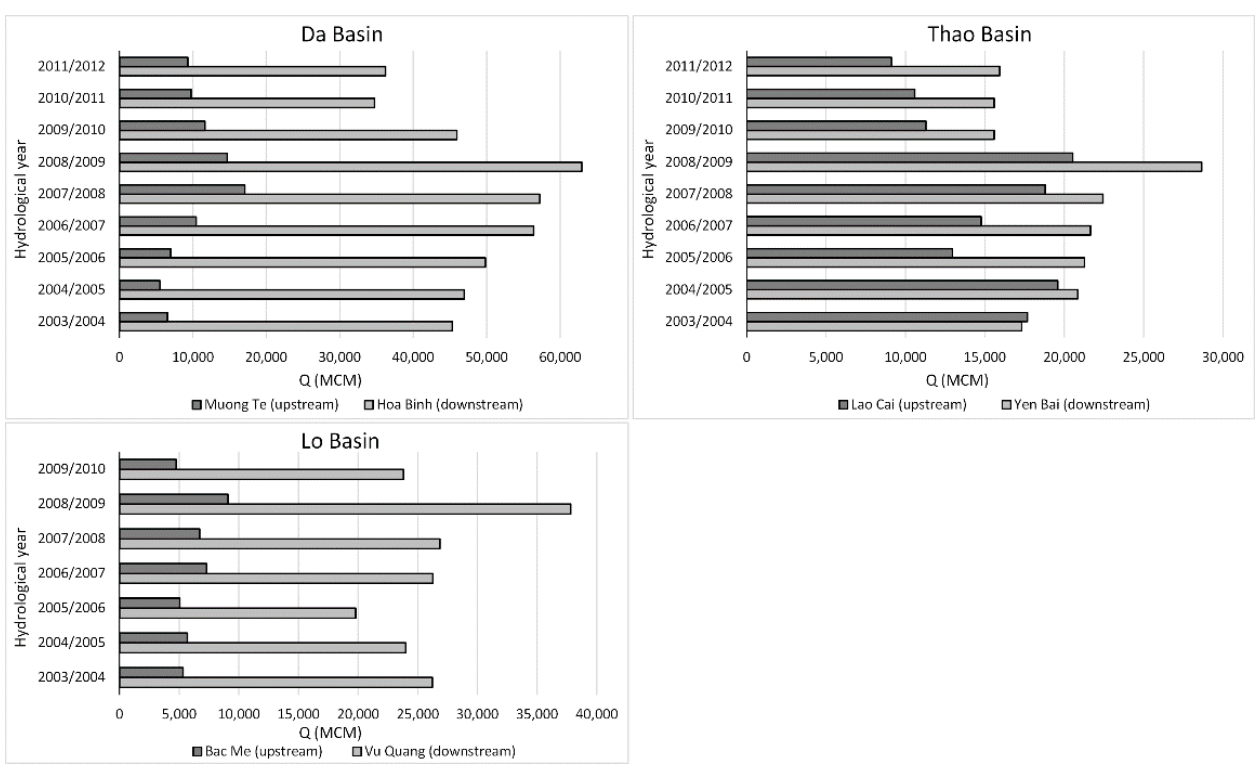

Figure A5. Runoff in million cubic meters (MCM) generated per hydrological year in each of the subbasins, according to streamflow $(\mathrm{Q})$ records. 


\section{References}

1. Haddeland, I.; Heinke, J.; Biemans, H.; Eisner, S.; Flörke, M.; Hanasaki, N.; Konzmann, M.; Ludwig, F.; Masaki, Y.; Schewe, J.; et al. Global water resources affected by human interventions and climate change. PNAS 2014, 111, 3251-3256. [CrossRef] [PubMed]

2. Wada, Y.; Bierkens, M.F.P. Sustainability of global water use: Past reconstruction and future projections. Environ. Res. Lett. 2014, 9, 104003. [CrossRef]

3. Gleeson, T.; Wada, Y.; Bierkens, M.F.P.; van Beek, L.P.H. Water balance of global aquifers revealed by groundwater footprint. Nature 2012, 488, 197-200. [CrossRef] [PubMed]

4. Simons, G.W.H.; Bastiaanssen, W.G.M.; Immerzeel, W.W. Water reuse in river basins with multiple users: A literature review. J. Hydrol. 2015, 522, 558-571. [CrossRef]

5. Droogers, P.; Bouma, J. Simulation modelling for water governance in basins. Int. J. Water Resour. Dev. 2014, 30, 1-20. [CrossRef]

6. Hoekstra, A.Y.; Chapagain, A.K.; Aldaya, M.M.; Mekonnen, M.M. The Water Footprint Assessment Manual; Earthscan Ltd: London, UK, 2011.

7. Karimi, P.; Bastiaanssen, W.G.M.; Molden, D. Water Accounting Plus (WA+)—A water accounting procedure for complex river basins based on satellite measurements. Hydrol. Earth Syst. Sci. 2013, 17, 2459-2472. [CrossRef]

8. United Nations. SEEA-Water System of Environmental-Economic Accounting for Water; United Nations: New York, NY, USA, 2012.

9. Ahmad, M.U.D.; Bastiaanssen, W.G.M. Retrieving soil moisture storage in the unsaturated zone using satellite imagery and bi-annual phreatic surface fluctuations. Irrig. Drain. Syst. 2003, 17, 141-161. [CrossRef]

10. Kidd, C.; Levizzani, V. Status of satellite precipitation retrievals. Hydrol. Earth Syst. Sci. 2011, 15, 1109-1116. [CrossRef]

11. Anderson, M.C.; Allen, R.G.; Morse, A.; Kustas, W.P. Use of Landsat thermal imagery in monitoring evapotranspiration and managing water resources. Remote Sens. Environ. 2012, 122, 50-65. [CrossRef]

12. Karimi, P.; Bastiaanssen, W.G.M. Spatial evapotranspiration, rainfall and land use data in water accounting-Part 1: Review of the accuracy of the remote sensing data. Hydrol. Earth Syst. Sci. 2015, 19, 507-532. [CrossRef]

13. Asadullah, A.; McIntyre, N.; Kigobe, M. Evaluation of five satellite products for estimation of rainfall over Uganda/Evaluation de cinq produits satellitaires pour l'estimation des précipitations en Ouganda. Hydrol. Sci. J. 2008, 53, 1137-1150. [CrossRef]

14. Stisen, S.; Sandholt, I. Evaluation of remote-sensing-based rainfall products through predictive capability in hydrological runoff modelling. Hydrol. Process. 2010, 24, 879-891. [CrossRef]

15. Hessels, T.M. Comparison and Validation of Several Open Access Remotely Sensed Rainfall Products for the Nile Basin. Master's Thesis, Delft University of Technology, Delft, The Netherlands, 2015.

16. Khandu; Awange, J.L.; Forootan, E. An evaluation of high-resolution gridded precipitation products over Bhutan (1998-2012). Int. J. Climatol. 2015, 36, 1067-1087. [CrossRef]

17. Liu, J.; Duan, Z.; Jiang, J.; Zhu, A. Evaluation of three satellite precipitation products TRMM 3B42, CMORPH, and PERSIANN over a Subtropical Watershed in China. Adv. Meteorol. 2015. [CrossRef]

18. Toté, C.; Patricio, D.; Boogaard, H.; van der Wijngaart, R.; Tarnavsky, E.; Funk, C. Evaluation of satellite rainfall estimates for drought and flood monitoring in Mozambique. Remote Sens. 2015, 7, 1758-1776. [CrossRef]

19. Mora, B.; Tsendbazar, N.E.; Herold, M.; Arino, O. Global land cover mapping: Current status and future trends. In Land Use and Land Cover Mapping in Europe; Manakos, I., Braun, M., Eds.; Springer: Heidelberg, Germany, 2014; pp. 411-427.

20. Tsendbazar, N.E.; de Bruin, S.; Herold, M. Assessing global land cover reference datasets for different user communities. ISPRS J. Photogramm. Remote Sens. 2014, 103, 93-114. [CrossRef]

21. Kalma, J.D.; McVicar, T.R.; McCabe, M.F. Estimating land surface evaporation: A review of methods using remotely sensed surface temperature data. Surv. Geophys. 2008, 29, 421-469. [CrossRef]

22. Mu, Q.; Zhao, M.; Running, S.W. MODIS Global Terrestrial Evapotranspiration (ET) Product (MOD16A2/A3)_Algorithm Theoretical Basis Document Collection 5; NASA: Washington, DC, USA, 2013. 
23. Senay, G.B.; Bohms, S.; Singh, R.K.; Gowda, P.H.; Velpuri, N.M.; Alemu, H.; Verdin, J.P. Operational evapotranspiration mapping using remote sensing and weather datasets: A new parameterization for the SSEB approach. J. Am. Water Resour. Assoc. 2013, 49, 577-591. [CrossRef]

24. Guerschman, J.P.; Van Dijk, A.I.J.M.; Mattersdorf, G.; Beringer, J.; Hutley, L.B.; Leuning, R.; Pipunic, R.C.; Sherman, B.S. Scaling of potential evapotranspiration with MODIS data reproduces flux observations and catchment water balance observations across Australia. J. Hydrol. 2009, 369, 107-119. [CrossRef]

25. Chen, X.; Su, Z.; Ma, Y.; Yang, K.; Wen, J.; Zhang, Y. An improvement of roughness height parameterization of the Surface Energy Balance System (SEBS) over the Tibetan plateau. J. Appl. Meteorol. Climatol. 2013, 52, 607-622. [CrossRef]

26. Anderson, M.C.; Kustas, W.P.; Norman, J.M.; Hain, C.R.; Mecikalski, J.R.; Schultz, L.; González-Dugo, M.P.; Cammalleri, C.; D’Urso, G.; Pimstein, A.; et al. Mapping daily evapotranspiration at field to continental scales using geostationary and polar orbiting satellite imagery. Hydrol. Earth Syst. Sci. 2011, 15, 223-239. [CrossRef]

27. Velpuri, N.M.; Senay, G.B.; Singh, R.K.; Bohms, S.; Verdin, J.P. A comprehensive evaluation of two MODIS evapotranspiration products over the conterminous United States: Using point and gridded FLUXNET and water balance ET. Remote Sens. Environ. 2013, 139, 35-49. [CrossRef]

28. Alemu, H.; Senay, G.; Kaptue, A.; Kovalskyy, V. Evapotranspiration variability and its association with vegetation dynamics in the Nile Basin, 2002-2011. Remote Sens. 2014, 6, 5885-5908. [CrossRef]

29. Hu, G.; Jia, L.; Menenti, M. Comparison of MOD16 and LSA-SAF MSG evapotranspiration products over Europe for 2011. Remote Sens. Environ. 2015, 156, 510-526. [CrossRef]

30. Hu, G.; Jia, L. Monitoring of evapotranspiration in a Semi-Arid Inland River Basin by combining microwave and optical remote sensing observations. Remote Sens. 2015, 7, 3056-3087. [CrossRef]

31. Yilmaz, M.T.; Anderson, M.C.; Zaitchik, B.; Hain, C.R.; Crow, W.T.; Ozdogan, M.; Chun, J.A.; Evans, J. Comparison of prognostic and diagnostic surface flux modeling approaches over the Nile River basin. Water Resour. Res. 2014, 50, 386-408. [CrossRef]

32. Trambauer, P.; Dutra, E.; Maskey, S.; Werner, M.; Pappenberger, F.; Van Beek, L.P.H.; Uhlenbrook, S. Comparison of different evaporation estimates over the African continent. Hydrol. Earth Syst. Sci. 2014, 18, 193-212. [CrossRef]

33. Singh, R.; Senay, G. Comparison of four different energy balance models for estimating evapotranspiration in the Midwestern United States. Water 2015, 8. [CrossRef]

34. Bhattarai, N.; Shaw, S.B.; Quackenbush, L.J.; Im, J.; Niraula, R. Evaluating five remote sensing based single-source surface energy balance models for estimating daily evapotranspiration in a humid subtropical climate. Int. J. Appl. Earth Obs. Geoinf. 2016, 49, 75-86. [CrossRef]

35. Bastiaanssen, W.; Karimi, P.; Rebelo, L.-M.; Duan, Z.; Senay, G.; Muttuwatte, L.; Smakhtin, V. Earth observation based assessment of the water production and water consumption of Nile Basin agro-ecosystems. Remote Sens. 2014, 6, 10306-10334. [CrossRef]

36. Wang-Erlandsson, L.; Bastiaanssen, W.G.M.; Gao, H.; Jägermeyr, J.; Senay, G.B.; Van Dijk, A.I.J.M.; Guerschman, J.P.; Keys, P.W.; Gordon, L.J.; Savenije, H.H.G. Global root zone storage capacity from satellite-based evaporation. Hydrol. Earth Syst. Sci. Discuss. 2016. [CrossRef]

37. Hain, C.R.; Crow, W.T.; Anderson, M.C.; Yilmaz, M.T. Diagnosing neglected soil moisture source-Sink processes via a thermal infrared-Based two-source energy balance model. J. Hydrometeorol. 2015, 16, 1070-1086. [CrossRef]

38. Li, Y.; He, D.; Ye, C. Spatial and temporal variation of runoff of red river basin in Yunnan. J. Geogr. Sci. 2008, 18, 308-318. [CrossRef]

39. Le, T.P.Q.; Seidler, C.; Kändler, M.; Tran, T.B.N. Proposed methods for potential evapotranspiration calculation of the Red River basin (North Vietnam). Hydrol. Process. 2012, 26, 2782-2790. [CrossRef]

40. Van Diep, N.; Khanh, N.H.; Son, N.M.; Van Hanh, N.; Huntjens, P. Integrated water resource management in the Red River Basin-Problems and cooperation opportunity. In Proceedings of the CAIWA International Conference on Adaptive and Integrated Water Management, Basel, Switzerland, 2-10 September 2007.

41. Zhongyan, H. Changes of dry-wet climate in the dry season in Yunnan (1961-2007). Adv. Clim. Chang. Res. 2012, 2, 49-54.

42. Kattelus, M.; Kummu, M.; Keskinen, M.; Salmivaara, A.; Varis, O. China's southbound transboundary river basins: A case of asymmetry. Water Int. 2014, 40, 113-138. [CrossRef] 
43. Castelletti, a.; Pianosi, F.; Quach, X.; Soncini-Sessa, R. Assessing water reservoirs management and development in northern Vietnam. Hydrol. Earth Syst. Sci. 2012, 16, 189-199. [CrossRef]

44. Devienne, S. Red River Delta: Fifty years of change. Moussons 2006, 9-10, 255-280. [CrossRef]

45. Luu, T.N.M.; Garnier, J.; Billen, G.; Orange, D.; Némery, J.; Le, T.P.Q.; Tran, H.T.; Le, L.A. Hydrological regime and water budget of the Red River Delta (Northern Vietnam). J. Asian Earth Sci. 2010, 37, 219-228. [CrossRef]

46. Klapetek, V.; Havrland, B.; Mazancova, J. Comparison of lowland rice irrigation systems in the red river basin (vietnam). Agric. Trop. Subtrop. 2010, 43, 113-118.

47. Van Le, C. Return Flow and Reuse of Drainage Water in a Rice-Based Irrigation and Drainage Area in the Red River Basin, Vietnam; Faculty of Science, University of Copenhagen: Copenhagen, Denmark, 2012.

48. Bui, D.D.; Kawamura, A.; Tong, T.N.; Amaguchi, H.; Nakagawa, N.; Iseri, Y. Identification of aquifer system in the whole Red River Delta, Vietnam. Geosci. J. 2011, 15, 323-338. [CrossRef]

49. Vu, D.V.; Ouillon, S.; Tran, D.T.; La, V.C. Impact of the Hoa Binh Dam (Vietnam) on water and sediment budgets in the Red River basin and delta. 2014, 18, 333-370. [CrossRef]

50. Gong, P.; Wang, J.; Yu, L.; Zhao, Y.; Zhao, Y.; Liang, L.; Niu, Z.; Huang, X.; Fu, H.; Liu, S.; et al. Finer resolution observation and monitoring of global land cover: First mapping results with Landsat TM and ETM+ data. Int. J. Remote Sens. 2013, 34, 2607-2654. [CrossRef]

51. Chen, J.; Chen, J.; Liao, A.; Cao, X.; Chen, L.; Chen, X.; He, C.; Han, G.; Peng, S.; Lu, M.; et al. Global land cover mapping at $30 \mathrm{~m}$ resolution: A POK-based operational approach. ISPRS J. Photogramm. Remote Sens. 2015, 103, 7-27. [CrossRef]

52. Defourny, P.; Bicheron, P.; Brockmann, C.; Bontemps, S.; Van Bogaert, E.; Arino, O. The first $300 \mathrm{~m}$ global land cover map for 2005 using ENVISAT MERIS time series: A product of the GlobCover system. Proc. ISRSE 2009, 22, 1-4.

53. Tateishi, R.; Hoan, N.T.; Kobayashi, T.; Alsaaideh, B.; Tana, G.; Phong, D.X. Production of global land cover data-GLCNMO2008. J. Geogr. Geol. 2014, 6. [CrossRef]

54. NASA's Goddard Space Flight Center MODIS Data Products. Available online: http://modis.gsfc.nasa.gov/ (accessed on 23 March 2016).

55. Yu, L.; Wang, J.; Gong, P. Improving $30 \mathrm{~m}$ global land-cover map FROM-GLC with time series MODIS and auxiliary data sets: A segmentation-based approach. Int. J. Remote Sens. 2013, 34, 5851-5867. [CrossRef]

56. Vuolo, F.; Atzberger, C. Improving land cover maps in areas of disagreement of existing products using NDVI time series of MODIS-Example for Europe\&lt;BR\&gt;Verbesserung von Landbedeckungskarten in Gebieten widersprüchlicher Grundlagen mit Hilfe der NDVI-Zeitreihe von MODIS—B. Photogramm. Fernerkund. Geoinf. 2014, 2014, 393-407.

57. Johnston, R.; Hoanh, C.T.; Lacombe, G.; Lefroy, R.; Pavelic, P.; Fry, C. Managing Water in Rainfed Agriculture in the Greater Mekong Subregione. Available online: http://agris.fao.org/agris-search/ search.do?recordID=QL2013000139 (accessed on 23 March 2016).

58. Nguyen, D.; Wagner, W.; Naeimi, V.; Cao, S. Rice-planted area extraction by time series analysis of ENVISAT ASAR WS data using a phenology-based classification approach: A case study for Red River Delta, Vietnam. ISPRS Int. Arch. Photogramm. Remote Sens. Spat. Inf. Sci. 2015, XL-7/W3, 77-83. [CrossRef]

59. Bontemps, S.; Defourny, P.; van Bogaert, E.; Arino, O.; Kalogirou, V.; Perez, J.R. Globcover 2009: Products Desciption and Validation Report. Available online: http://www.citeulike.org/group/15400/article/ 12770349 (accessed on 23 March 2016).

60. IWMI Irrigated Area Map: Asia. Available online: http://waterdata.iwmi.org/Applications/IRRA/ (accessed on 23 March 2016).

61. Vietnam Red River Delta Irrigation Management: Incomplete Recognition of Local Institutional Innovations. Available online: http://agris.fao.org/agris-search/search.do?recordID=GB2013201092 (accessed on 23 March 2016).

62. Turral, H.; Malano, H.; Chien, N.V.; Esum, R. Development and specification of a service agreement and operational rules for La Khe irrigation system, Ha Dong, Vietnam. Irrig. Drain. 2002, 51, 129-140. [CrossRef]

63. Nguyen, T.H. Improving Water Security for the Future through IWRM and Better Water Governance in the Red-ThaiBinh river basin (Vietnam). Available online: http://www.tecniberia.es/jornadas/ documentos/papers/13_nguyen thuy hang_paper.pdf (accessed on 23 March 2016).

64. Huffman, G.J.; Bolvin, D.T. TRMM and Other Data Precipitation Data Set Documentation; NASA: Greenbelt, MD, USA, 2013. 
65. Funk, C.C.; Peterson, P.J.; Landsfeld, M.F.; Pedreros, D.H.; Verdin, J.P.; Rowland, J.D.; Romero, B.E.; Husak, G.J.; Michaelsen, J.C.; Verdin, A.P. A quasi-global precipitation time series for drought monitoring. US Geol. Surv. Data Ser. 2014, 832, 4.

66. Joyce, R.J.; Janowiak, J.E.; Arkin, P.A.; Xie, P. CMORPH: A method that produces global precipitation estimates from passive microwave and infrared data at high spatial and temporal resolution. J. Hydrometeorol. 2004, 5, 487-503. [CrossRef]

67. Liu, T.; Liu, L.; Luo, Y.; Lai, J. Simulation of groundwater evaporation and groundwater depth using SWAT in the irrigation district with shallow water table. Environ. Earth Sci. 2015, 74, 315-324. [CrossRef]

68. Le, T.; Al-Juaidi, F.; Sharif, H. Hydrologic simulations driven by satellite rainfall to study the hydroelectric development impacts on river flow. Water 2014, 6, 3631-3651. [CrossRef]

69. Cheema, M.J.M.; Bastiaanssen, W.G.M. Local calibration of remotely sensed rainfall from the TRMM satellite for different periods and spatial scales in the Indus Basin. Int. J. Remote Sens. 2012, 33, 2603-2627. [CrossRef]

70. Vernimmen, R.R.E.; Hooijer, A.; Mamenun; Aldrian, E.; van Dijk, A.I.J.M. Evaluation and bias correction of satellite rainfall data for drought monitoring in Indonesia. Hydrol. Earth Syst. Sci. 2012, 16, 133-146. [CrossRef]

71. Anderson, M.C.; Norman, J.M.; Mecikalski, J.R.; Otkin, J.A.; Kustas, W.P. A climatological study of evapotranspiration and moisture stress across the continental United States based on thermal remote sensing: 2. Surface moisture climatology. J. Geophys. Res. Atmos. 2007, 112, 1-13. [CrossRef]

72. Savoca, M.E.; Senay, G.B.; Maupin, M.A.; Kenny, J.F.; Perry, C.A. Actual Evapotranspiration Modeling Using the Operational Simplified Surface Energy Balance (SSEBop) Approach; Scientific Investigations Report 2013-5126; US Geological Survey: Reston, Virginia, 2013.

73. Anderson, M.C.; Zolin, C.A.; Hain, C.R.; Semmens, K.; Tugrul Yilmaz, M.; Gao, F. Comparison of satellite-derived LAI and precipitation anomalies over Brazil with a thermal infrared-based evaporative stress index for 2003-2013. J. Hydrol. 2015, 526, 287-302. [CrossRef]

74. Zomer, R.J.; Trabucco, A.; Bossio, D.A.; Verchot, L.V. Climate change mitigation: A spatial analysis of global land suitability for clean development mechanism afforestation and reforestation. Agric. Ecosyst. Environ. 2008, 126, 67-80. [CrossRef]

75. Duc, N.H.; Shintani, T.; Umeyama, M. Estimation of freshwater-discharge distribution for multi-estuary branches in the Red River System in Vietnam. In Proceedings of the 34th World Congress of the International Association for Hydro-Environment Research and Engineering, Brisbane, Australia, 26 June-1 July 2011.

76. McMillan, H.; Krueger, T.; Freer, J. Benchmarking observational uncertainties for hydrology: Rainfall, river discharge and water quality. Hydrol. Process. 2012, 26, 4078-4111. [CrossRef]

77. Di Baldassarre, G.; Montanari, A. Uncertainty in river discharge observations: A quantitative analysis. Hydrol. Earth Syst. Sci. 2009, 13, 913-921. [CrossRef]

78. Pelletier, P.M. Uncertainties in the single determination of river discharge: A literature review. Can. J. Civ. Eng. 1988, 15, 834-850. [CrossRef]

79. Hofste, R.W. Comparative Analysis among Near-Operational Evapotranspiration Products for the Nile Basin Based on Earth Observations; Delft University of Technology: Delft, The Netherlands, 2014.

80. Kono, Y.; Tuan, D.D. Effect of water control on rice cultivation in the Red River Delta, Vietnam: A case study in the Nhue River irrigation system. Southeast Asian Stud. 1995, 32, 425-445.

81. IMRR. IMRR Project Report: System Characterization; Politecnico di Milano: Milano, Italy, 2011.

82. Van De Giesen, N.; Rutten, M.; Coerver, B.; Simons, G. Demonstration of an operational decision support system for reservoir managers in the Da River based on open-access remote sensing data and models. In Vietnam Water Cooperation Initiative (VACI); NAWAPI: Hanoi, Vietnam, 2015.

83. Liu, B.M.; Collick, A.S.; Zeleke, G.; Adgo, E.; Easton, Z.M.; Steenhuis, T.S. Rainfall-discharge relationships for a monsoonal climate in the Ethiopian highlands. Hydrol. Process. 2008, 22, 1059-1067. [CrossRef]

84. Easton, Z.; Awulachew, S.; Steenhuis, T. Hydrological processes in the Blue Nile. In The Nile River Basin-Water, Agriculture, Governance and Livelihoods; International Water Management Institute: Colombo, Sri Lanka, 2012.

85. Ngo, L. Optimising Reservoir Operation; Technical University of Denmark: Kongens Lyngby, Denmark, 2006.

86. Holmes, T.R.H.; Crow, W.T.; Hain, C.; Anderson, M.C.; Kustas, W.P. Diurnal temperature cycle as observed by thermal infrared and microwave radiometers. Remote Sens. Environ. 2015, 158, 110-125. [CrossRef] 
87. Immerzeel, W.W.; Droogers, P. Calibration of a distributed hydrological model based on satellite evapotranspiration. J. Hydrol. 2008, 349, 411-424. [CrossRef]

88. Vervoort, R.W.; Miechels, S.F.; van Ogtrop, F.F.; Guillaume, J.H.A. Remotely sensed evapotranspiration to calibrate a lumped conceptual model: Pitfalls and opportunities. J. Hydrol. 2014, 519, 3223-3236. [CrossRef]

89. Carroll, R.W.H.; Pohll, G.M.; Morton, C.G.; Huntington, J.L. Calibrating a basin-scale groundwater model to remotely sensed estimates of groundwater evapotranspiration. JAWRA J. Am. Water Resour. Assoc. 2015, 51, 1114-1127. [CrossRef]

90. Muthuwatta, L.A.L.P.; Booij, M.J.; Rientjes, T.O.M.H.M. Calibration of a semi-distributed hydrological model using discharge and remote sensing data. New App. Hydrol. Predict. Data Sparse Reg. 2009, 333, 52-58.

91. Livneh, B.; Lettenmaier, D.P.D. Multi-criteria parameter estimation for the unified land model. Hydrol. Earth Syst. Sci. 2012, 16, 3029-3048. [CrossRef]

92. Winsemius, H.C.; Savenije, H.H.G.; Bastiaanssen, W.G.M. Constraining model parameters on remotely sensed evaporation: Justification for distribution in ungauged basins? Hydrol. Earth Syst. Sci. 2008, 12, 1403-1413. [CrossRef]

93. Cheema, M.J.M.; Immerzeel, W.W.; Bastiaanssen, W.G.M. Spatial quantification of groundwater abstraction in the irrigated Indus Basin. Groundwater 2014, 52, 25-36. [CrossRef] [PubMed]

94. Van Eekelen, M.W.; Bastiaanssen, W.G.M.; Jarmain, C.; Jackson, B.; Ferreira, F.; van der Zaag, P.; Saraiva Okello, A.; Bosch, J.; Dye, P.; Bastidas-Obando, E.; et al. A novel approach to estimate direct and indirect water withdrawals from satellite measurements: A case study from the Incomati basin. Agric. Ecosyst. Environ. 2015, 200, 126-142. [CrossRef]

95. Bierkens, M.F.P. Global hydrology 2015: State, trends, and directions. Water Resour. Res. 2015, 51, $4923-4947$. [CrossRef]

96. Döll, P.; Douville, H.; Güntner, A.; Müller Schmied, H.; Wada, Y. Modelling freshwater resources at the Global Scale: Challenges and prospects. Surv. Geophys. 2015, 37, 195-221. [CrossRef]

97. Sood, A.; Smakhtin, V. Global hydrological models: A review. Hydrol. Sci. J. 2014, 60, 549-565. [CrossRef]

98. Bierkens, M.F.P.; Bell, V.A.; Burek, P.; Chaney, N.; Condon, L.E.; David, C.H.; de Roo, A.; Döll, P.; Drost, N.; Famiglietti, J.S.; et al. Hyper-resolution global hydrological modelling: what is next? Hydrol. Process. 2015, 29, 310-320. [CrossRef]

99. Jägermeyr, J.; Gerten, D.; Heinke, J.; Schaphoff, S.; Kummu, M.; Lucht, W. Water savings potentials of irrigation systems: Global simulation of processes and linkages. Hydrol. Earth Syst. Sci. 2015, 19, 3073-3091. [CrossRef]

100. Wada, Y.; Wisser, D.; Bierkens, M.F.P. Global modeling of withdrawal, allocation and consumptive use of surface water and groundwater resources. Earth Syst. Dyn. 2014, 5, 15-40. [CrossRef]

101. Peña-Arancibia, J.L.; Mainuddin, M.; Kirby, J.M.; Chiew, F.H.S.; McVicar, T.R.; Vaze, J. Assessing irrigated agriculture's surface water and groundwater consumption by combining satellite remote sensing and hydrologic modelling. Sci. Total Environ. 2016, 542, 372-382. [CrossRef] [PubMed]

102. Vandecasteele, I.; Bianchi, A.; Batista E Silva, F.; Lavalle, C.; Batelaan, O. Mapping current and future European public water withdrawals and consumption. Hydrol. Earth Syst. Sci. 2014, 18, 407-416. [CrossRef]

103. Yamada, H.G.; Yoshikawa, S.; Koirala, S.; Kanae, S. Spatial and temporal estimation of global water withdrawals from 1950 to 2000 based on statistical data. J. Jpn. Soc. Civ. Eng. Ser. B1 Hydraul. Eng. 2012, 68, I_217-I_222. [CrossRef]

104. Droogers, P.; Immerzeel, W.W.; Lorite, I.J. Estimating actual irrigation application by remotely sensed evapotranspiration observations. Agric. Water Manag. 2010, 97, 1351-1359. [CrossRef]

105. Santos, C.; Lorite, I.J.; Tasumi, M.; Allen, R.G.; Fereres, E. Integrating satellite-based evapotranspiration with simulation models for irrigation management at the scheme level. Irrig. Sci. 2008, 26, 277-288. [CrossRef]

(C) 2016 by the authors; licensee MDPI, Basel, Switzerland. This article is an open access article distributed under the terms and conditions of the Creative Commons by Attribution (CC-BY) license (http://creativecommons.org/licenses/by/4.0/). 